\title{
STOCK RETURNS, VOLATILITY AND MEAN REVERSION IN EMERGING AND DEVELOPED FINANCIAL MARKETS
}

\author{
Rizwan Raheem AHMED ${ }^{1}$, Jolita VVEINHARDT ${ }^{2}$, Dalia ŠTREIMIKIENË ${ }^{2 *}$, \\ Saghir Pervaiz GHAURI ${ }^{1}$, Muhammad ASHRAF ${ }^{1}$ \\ ${ }^{1}$ Faculty of Management Sciences, Indus University, Block-17, \\ Gulshan, Karachi-75500, Pakistan \\ ${ }^{2}$ Institute of Sport Science and Innovations, Lithuanian Sports University, \\ Sporto g. 6, LT-4422, Lithuania
}

Received 21 November 2016; accepted 22 April 2017

\begin{abstract}
The objective of this research is to measure and examine volatilities between important emerging and developed stock markets and to ascertain a relationship between volatilities and stock returns. This research paper also analyses the Mean reversion phenomenon in emerging and developed stock markets. For this purpose, seven emerging markets and five developed markets were considered. Descriptive statistics showed that the emerging markets have higher returns with the higher risk-return trade-off. In contrast, developed markets have low annual returns with a low risk-return trade-off. Correlation analysis indicated the significant positive correlation among the developed markets, but emerging and developed markets have shown relatively insignificant correlation. Results of ARCH and GARCH revealed that the value of likelihood statistics ratio is large, that entails the GARCH $(1,1)$ model is a lucrative depiction of daily return pattern, that effectively and efficiently capturing the orderly reliance of volatility. The findings of the study showed that the estimate ' $\beta$ ' coefficients given in conditional variance equation are significantly higher than the ' $\alpha$ ', this state of affair entails that bigger market surprises tempt comparatively small revision in future volatility. Lastly, the diligence of the conditional variance estimated by $\alpha+\beta$ is significant and proximate to integrated GARCH $(1,1)$ model, thus, this indicates, the existing evidence is also pertinent in order to forecast the future volatility. The results signified that the sum of GARCH $(1,1)$ coefficients for all the equity returns' is less than 1 that is an important condition for mean reversion, as the sum gets closer to 1 , hence the Mean reversion process gets slower for all the emerging and developed stock markets.
\end{abstract}

Keywords: ARCH \& GARCH, volatility, stock returns, developed \& emerging stock markets, mean reversion.

JEL Classification: C32, G12, G15.

*Corresponding author. E-mail: dalia.streimikiene@lsu.lt 


\section{Introduction}

The finance literature draws the line of distinction and segments the stock markets into emerging and developed. Such distinction is made on the basis of varied stock market characteristics. The developed markets of the world are often considered as more liquid and efficient markets. Whereas, emerging markets are at the little low ebb. However, finance theory lauds that high order volatility is linked with higher stock returns in emerging markets. During last decade several stock markets experienced substantial evolution; emerging markets specifically reported exponential growth in market capitalization, a number of listed companies and trading volume (e.g., Bahloul, Bouri 2016; Choi et al. 2016; Goetzmann, Jorion 1999; etc.). Despite the fact that numerous emerging markets have started their journey to integrate with the global capital market (e.g., Koulakiotis et al. 2016; Bekaert et al. 1997; etc.), however such markets are yet unique from developed markets. Such distinction is again in terms of excessive risk attached to liquidity, inadequate quality of business, and much more.

Global Trade liberalization has opened the diverse avenues for investors to select and manage varied portfolios across the world. The globalization of stock markets has won the substantial amount of confidence of investors to put their holdings in any financially lucrative part of the world. The relaxations in investment embargos in stock markets not only expanded the investments returns but also became the source of integration of several stock markets (e.g., Kundu, Sarkar 2016; Naghavi, Lau 2016; etc.). The sufferings of unified common financial crises in several equity markets are one of the significant grounds of integration of equity markets. The information about spillover financial knowledge traveling from one equity market to another gained a reasonable consideration during last few decades. The main objective of the research is to investigate the patterns of market integration in terms of stock returns and volatility, as the two integrated markets may not offer paybacks of portfolio diversification (e.g., Caporale, Sousa 2016; Bouri, Demirer 2016; Jebran, Iqbal 2016; etc.).

Several researchers have studied the influence of volatility among distinct equity markets and mean-reverting phenomenon in these markets also. The majority of the scholars have investigated the volatility spillover effects among developed markets. However, some scholarly evidence about an investigation of developing and emerging equity markets are there as well. Several studies making developed equity markets as subject of interest such as: (e.g., Xiao, Dhesi 2010; Diebold, Yilmaz 2009; Harris, Pisedtasalasai 2006; Wagner, Szimayer 2004; Ng 2000; Chou et al. 1999; Hu et al. 1997; Li et al. 2016; Cakici et al. 2016; etc.). The research studies about developing and emerging equity markets have been concluded by Mirza et al. (2016), Ghosh and Saggar (2016), Günay (2016), Worthington and Higgs (2004), Beirne et al. (2013), Mukherjee and Mishra (2010), Choo et al. (2011), Joshi (2011), Sakthivel et al. (2012). These studies offered significant insights regarding assimilation among equity markets and offer capitalists efficient venture chances in various portfolios.

The equity market literature provides number of findings identifying the prevalence high order volatility and price fluctuations in developed and emerging markets (e.g., Richards 1996; Bekaert, Harvey 1997; Bekaert et al. 1998; Kawakatsu, Morey 1999; Harvey et al. 2000; Salomons, Grootveld 2003; Yarovaya et al. 2016; Sehgal, Garg 2016; etc.). In this regard, comparative analysis with developed equity markets, identifying similar peculiarities among 
emerging markets with country risk factors like financial, economic and political risks have been examined. Eventually, high order risk, in general has been linked with emerging markets. Such high risk returns, the high anticipation of investment returns in these markets. However, scholars (e.g., Yang, Liu 2016; Yavas, Rezayat 2016; Mosquera et al. 2016; Harvey 1995; Bekaert 1995; etc.) have documented counter evidence.

The objective and motivation of the research. The aim of this research study is to follow a well-known theoretical framework of risk and returns association in seven emerging and five developed stock markets. Additionally, to ascertain an association through a stochastic framework of analysis between equity returns and volatility followed by the presence of $\mathrm{ARCH}$ and GARCH effects. Another, important objective is to check the Mean reversion process for these markets, if so, slow or fast because it helps in forecasting the future volatilities and returns. The prime motivation for conducting this study is to examine (a) if emerging market proceeds are uncovered to supplemented volatility compared to developed markets, (b) how the realized stock prices of proceeds weigh against each other, (c) whether the occurrence of risk characteristics between two distinct kinds of markets is measurable, (d) how persistent these outcomes are covering the period from 2000 to 2016, e) our research study comprises of six biggest and three best performing emerging stock markets of 2016 of the World, and f) time-varying factor motivates to reinvestigate the previous findings, $g$ ) finally, the tapering or reduction of $\mathrm{QE}$ at what extent causes serious outflows of investment from the emerging markets? Thus, the study also examined to bridge this research gap.

Novelty and significance of the research. The novelty and significance of this research is many folds. This investigation mainly aims to evaluate the association of volatility and stock returns among emerged and developed stock markets. The intention to analyze the stock markets of several countries provides an efficient intelligence to stock investors. This research has focused on two selected markets of the South Asia (KSE100 and SENSEX), whereas, six markets of the Far East and the East Asia (Nikkei, JKSE, KLSE, KOSPI, HSI and SSE), one market from the Europe (DAX), one from Latin America (BVSP) and two markets from the North America (S\&P500 and Nasdaq). This study has used daily data of identified markets, which is considered as more reliable than weekly and monthly data among the circle of stock researchers because of the high frequency data, whereas, previous studies comprises of low frequency data (weekly or monthly). Therefore, the use of daily data is making study unique of its kind among stock market-related researches. The study has covered 16 and half years data including before and after global financial crunch of 2008, which is the handsome period for long-term analysis. The sample of this study is constituted on several dynamic stock markets, thus findings of this study will be the value addition to the diverse literature on stock market research. The performances of emerging markets including KSE100, BVSP, SENSEX, KLSE, and KOSPI is phenomenal in last three years, therefore, it is necessary to reinvestigate the behavior of these markets. Eventually, the stock investors will be benefitted in terms of efficient investment decisions.

The remainder part of this study is arranged into several sections: Section 1 focuses on extensive previous literature of emerging and developed equity markets, the data and methodology is discussed in Section 2, this section followed by the findings and results of the research in Section 3, whereas, the discussions and conclusion is presented in the last Section. 


\section{Theoretical substantiation}

The literary evidence from finance literature provides valuable insights regarding stock price volatility and returns spillover and its impact on the efficiencies of different stock markets. The current literature exhibited the mixed outcomes, both convergent and contradictory in several studies. Numerous research studies demonstrated that equity returns displayed unequal conditional volatilities energetically negative stuns having a greater influence on volatility than the positive shocks of the similar scale (e.g., Chiang, Doong 2001; Goudarzi, Ramamarayan 2011; Rafaqet, Afzal 2012; etc.). The results are not in lined with the previous research of Rousan and Al-Khouri (2005). However, few studies demonstrated the evidence of long memory, therefore, probabilities of forecasting future volatilities (e.g., McMillan, Thupayagale 2008; Cifter, Ozun 2008; Maheshchandra 2012; Banerjee, Sarkar 2006; Kasman, Torun 2007; etc.), whereas, some other research studies exhibited no evidence of long memory (e.g., Kilic 2004; Korkmaz et al. 2009; etc.). Hence, the confirmation is still not conclusive visà-vis the equity markets of developed and emerging economies. Okičić (2015) investigated the behavior of stock returns in Central and Eastern Europe (CEE) stock markets with the emphasis on the association between conditional volatility and stock returns. Findings of the study confirmed that ARIMA and GARCH provide confirmatory evidence that ARIMA and GARCH methods deliver thrifty estimations of mean and volatility approximations of mean and volatility subtleties in the case of CEE equity markets, moreover, they also confirmed the slow mean reversion process in CEE stock markets. There is overwhelming confirmation corroborating the presence of a leverage effect, it means that a number of negative shocks escalate volatility more as compared to the positive shocks do (Bahloul, Bouri 2016). For the intelligent investment decision in equity markets is based on the way of communication stock information from one market to another. The local and foreign investors lay more emphasis on the means of transmitting stock related information. The majority of researches studies have been undertaken to investigate the mode of business in developed markets; however, few studies can also be traced in finance literature focusing on emerging and developing markets. The literature review in this study is segmented into reviewing the studies focusing on developing, developed and emerging stock markets.

The researchers focused on the developed stock markets comprise such as, Frugier (2016), Xiao and Dhesi (2010), Diebold and Yilmaz (2009), Harris and Pisedtasalasai (2006), Wagner and Szimayer (2004), Ng (2000), Hu et al. (1997), Chou et al. (1999). Hu et al. (1997) investigated some selected emerging markets namely Taiwan, Hong Kong, Shanghai, Shenzhen and their nature of relationship with the American and Japanese equity markets. By employing the causality in variance test, the researchers found clear evidences signifying the existence of shock transmission and returns between Hong Kong and the American equity markets. Chou et al. (1999) found significant and justifying the existence of volatility and the stock association between Taiwan and the US equity markets, they have also concluded the slow mean reversion in these markets. Engle and Kroner (1995) have carried out an investigation by using MGARCH model also known as BEKK model. Their findings documented the evidence justifying the mean reversion and the spread of both variance and return between the US and Taiwan equity markets. Hoque and Chiou (2011) investigated the USA, the UK and 
Japanese equity markets covering the business period 1997 to 2007 and documented led lag association among the identified equity markets. The study conducted by Savva et al. (2009) exhibited the literary evidence validating the integration of the US equity markets with the European Union stock markets. Their study focused on the US equity markets and the EU stock markets, which included the UK, Germany, Italy, and France. Baele (2005) further extended the finance literature by studying the flow of volatility between the US and the EU markets. The researcher has taken 13 equity markets of the Europe, and taken weekly observations of equity returns. By using GARCH and GEKK models approach to analyze the data, the study found the escalating propensity of volatility for several markets during 1990s. The outcomes of the research further validated the evidence of volatility transmission from the US stock markets to Switzerland, Sweden and the UK equity markets.

Harris and Pisedtasalasai (2006) conducted the study by applying GARCH model technique carrying the purpose of investigating the mean and shock transmission, and the association between returns and volatilities among small and large equity markets of the UK. The study found that volatility often flows from the larger equity market to the smaller market in the UK. A novel extension were made to finance literature by studying the flow of volatility and relationship of stock returns and volatility among seven developed markets (UK, Hong Kong, USA, France and Japan) and 10 emerging stock markets (Malaysia, Mexico, Argentina, Chile, Thailand, Brazil, Taiwan, Philippines, South Korea and Singapore) considering the data before and after financial crunch in the Asia (Diebold, Yilmaz 2009). Their findings registered absence of the existing trend in the return and spillover, however, illustrated sturdiness with time. They documented integration and mean reversion phenomenon in several markets also. Xiao and Dhesi (2010) investigated the shock transmission and equity returns for four indices (CAC, DAX, S\&P500 and FTSE100) and found significant evidence justifying the existence of shock transmission amongst the US and the European equity markets. Their research outcomes showed the existence of evidence regarding spillover of volatility from the US equity markets to the most of selected EU stock markets.

The research studies focusing on emerging equity markets such as, Neaime (2016), Auer (2016), Guris and Sacildi (2016), Sarwar and Khan (2016), Worthington and Higgs (2004), Wang et al. (2005), Li and Majerowska (2008), Beirne et al. (2013), and Erb et al. (1997). Among these studies, Wang et al. (2005) conducted empirical analysis using EGARCH model found the confirmation of both returns and shock transmission from developed stock markets to emerging equity markets of the Asia. They also concluded slow mean reversion process in selected stock markets. The study also found the cross-border transmission of volatility and its influence on returns focusing on the Asian emerging markets. Another, important study of Li and Majerowska (2008), in which they compared Warsaw and Budapest equity markets with the US and Frankfurt markets. The BEKK GARCH model was used to examine the daily data. Their investigation emerged with statistically significant findings confirming the existence of spillover effect of volatility and its influence on stock returns of the US and DAX equity markets. Beirne et al. (2013) investigated the flow of shocks among newly emerged markets and developed markets. By using tri-variate GARCH model, they established the existence of clear substantiation regarding shock transmission from developed markets to emerging markets. 
The research studies focusing on developing countries' markets documented their empirical findings regarding confirmation of volatility transmission and its impact on stock returns (e.g., Borland 2016; Baruník et al. 2016; Singh et al. 2016; Sakthivel et al. 2012; Choo et al. 2011; Mukherjee, Mishra 2010; Joshi 2011; etc.). Mukherjee and Mishra (2010) have carried out an important study; they took 12 equity markets of the Asia, and major financial markets of the India. Using GARCH model, their investigation concluded the existence of bidirectional return spillover between Indian and all identified equity markets excluding Sri Lanka. Joshi (2011) found the evidence of bidirectional returns spillover and fluctuation among stock markets of the Asian countries, the study applied GARCH BEKK model for the equity markets of the Japan, South Korea, Indonesia, China, Hong Kong, and India. Choo et al. (2011) investigated volatility and stock return spillover between larger and smaller equity markets of Malaysia. Sakthivel et al. (2012) investigated co-movement of shock transmission and stock returns among markets of India, Japan, the USA, Australia and the UK. Their study also confirmed the existence of bidirectional spillover of shocks from Indian and the US Markets.

Scheicher (2001), and Serwa and Bohl (2005) argued that the local factors of Central and Eastern European (CEE) stock markets are the driving force for the volatilities of these equity markets. There is an increasing interdependence between CEE markets and developed stock markets of the EU (e.g., Chelley-Steeley 2005; Gelos, Sahay 2000; etc.). Égert and Kočenda (2007) did not find any significant co-movement and interdependence between CEECs (Czech Republic, Hungary and Poland) and the developed EU markets. However, they concluded a short-term spillover in both volatilities and returns for these markets. Caporale and Spagnolo (2010) examined the relation between three CEE countries (Czech Republic, Hungary and Poland) and stock markets of Russia and the UK. They concluded interdependence between two sets of markets, and further concluded the euro introduction caused increase in volatilities between CEE markets and the UK. Harrison and Moore (2010) concluded no evidence of cointegration between CEECs (Poland, Hungary, Czech Republic and Romania) and the equity markets of Germany and the UK, but increasing with the passage of time. Hanousek et al. (2009) and Hanousek and Kocenda (2009) examined and concluded that macroeconomic activities instigating from the developed markets, and affect the new evolving CEE markets. According to Mullineux and Murinde (2000) due to the small sizes of equity markets in CEECs, it is almost impossible to predict the degree of convergence of these new markets. Voronkova (2004) established the fact that linkage between the CEE equity markets and the developed EU markets is time varying.

Gilmore et al. (2008) examined and determined a dynamic cointegration and co-movement between financial markets of CEECs (Poland, Hungary, Czech Republic) and the developed EU markets. However, they did no have an evidence of significant convergence between the markets. Syriopoulos (2007) concluded that the CEE stock markets have strong correlation among the other matured and developed equity markets of the EU. According to Jochum et al. (1999), the Russian crises (1997-1998) have a great impact on the integration of equity markets of Hungary, Poland, and Czech Republic. During the crises these markets terminated their links between the Russian and the US markets. Michael and Köke (2002) established that there is no integration and co-movement between the stock returns 
of CEECs and the Russia. Gilmore and McManus (2002, 2003; etc.) established that there is no relationship and convergence between the CEE markets and the developed markets of the US and the Germany. Cappiello et al. (2006), and Savva and Aslanidis (2009) examined and concluded a conditional correlation and some degree of integration between CEECs and developed stock markets of the EU.

Contribution of the study in existing literature. The current study will be a significant addition in existing literature regarding the volatility, and equity relationship, and mean reversion process because we have not considered top developed and emerging markets of the world but we incorporated these markets from every content and corner of the world. Thus, in this way we also examine the geographic, cultural, financial, economic, social, legal, political and technological differences while conducting our research. The results of the previous researches are mixed, thus, the results are still inconclusive. Therefore, there is a need to reconfirm the behavior of developed and emerging stock markets. Since we have concluded from the previous literature the relationship between developed and emerging markets is time varying because nothing is constant and every factor is changes constantly (Auer 2016), hence, it is essential to reinvestigate this relationship. The previous literature also demonstrated that the CEEs markets' integration is much dependent on the financial markets of the Germany, the UK, the US, and other western developed financial markets, therefore, this research provides the basic foil to the researchers of CEEs countries as well. It is also concluded from the literature that the performance of both developed and emerging markets is quite different before and after financial crunch of 2007-08. Therefore, this research provides the answers of financial markets' performance before and after the financial crunch. The US central bank has introduced tapering or reduction of QE in 2013-14, and federal treasuries the interest up to 100 basis points, which creates the setback on monetary facilitation. Therefore, the tapering or reduction of QE causes serious outflows of investment from the emerging markets. According to a research, this tapering policy has a substantial influence on the emerging markets' spillover (Chen et al. 2014). Hence, this research also addresses this issue for developed and emerging markets after the introduction of tapering by the US this period.

Based on the discussed theoretical substantiation, following five hypotheses have been formulated for undertaken study:

$H_{1}$ : Markets' volatility and returns are positively associated

$\mathrm{H}_{2}$ : All market returns have equal Volatility

$\mathrm{H}_{3}$ : Market returns have ARCH effects

$\mathrm{H}_{4}$ : Market returns have GARCH effects

$\mathrm{H}_{5}$ : Market returns observe Mean Reversion

\section{Data and methodology}

Classification of stock markets. This investigation is focusing on national stock indices of established equity markets, which were classified by Morgan Stanley Capital International (MSCI). The financial markets are classified taking into account several factors including GDP, Per Capita Income, Perceived Investment risk, local government rules \& regulations for 
foreign ownership restrictions and financial jurisdiction etc. The emerging market index of MSCI actually evaluates the performance of equity markets in relation to worldwide equity markets.

As of 2016, seven emerging market indices: BVSP (Brazil), SSE (China), SENSEX (India), JKSE (Indonesia), KOSPI (South Korea), KLSE (Malaysia), and KSE100 (Pakistan) have been selected. As of 2016, the MSCI five developed equity markets are: DAX (Germany), HSI (Hong Kong), Nikkei225 (Japan), S\&P500 and Nasdaq (United States) have been selected for this research. The MSCI indices are believed as benchmark for measuring performance for global stock markets and are well recognized as parameters employed by global portfolio managers. Every state's stock indices are blend of stocks that comprehensively refers the stock composition of respective nation.

Data Collection. This research, data series covering the time span from January 1, 2000 to June 30,2016 . The period covered in this study is based on the data of 16 and half years with the objective to analyze comprehensively. The source for accumulating the data about developed and emerging markets for this study is from the website of Yahoo Finance. The biggest advantage to collect the data from Yahoo Finance is the real-time factor, and directly extracted in MS Excel files. The observations comprise of daily closing stock market indices. The countries selected for this study from the South Asia are Pakistan and India. Whereas, Korea, Japan, China, Hong Kong, Malaysia and Indonesia from the East Asia and the Far East Asia. However, Brazil is selected from Latin America. Germany is taken from the Europe and the United States from the North America. In Pakistan, Pakistan Stock Exchange (PSX) is the consolidated equity market has been made a part of the investigation for this study. From Korea, the Korea Composite Stock Price Index (KOSPI) has also been taken for this study. Shanghai stock exchange (SSE) has been acquired from China. Hang seng index (HSI) is selected from Hong Kong. This study has also made a point of investigation Nikkei225 from Japan. Jakarta Stock Exchange Composite Index (JKSE) is taken from Indonesia. Kuala Lumpur Stock Exchange (KLSE) has been considered from Malaysia. The index of Bolsa de Valores do Estado de São Paulo (BVSP) is taken from Brazil. The Deutsche Boerse AG German Stock Index DAX (DAX) is considered from Germany. Two most important stock exchanges, the Standard \& Poor's (S\&P500), and National Association of Securities Dealers Automated Quotations (NASDAQ) have been taken from the United States.

Estimation Models. The graphical representation of time series shows the preliminary examination of stock behaviors and the trend of the markets chosen for this study. Log returns for every chosen market are required to be modelled, succeeded by correlation ( $\mathrm{r}$ ), standard deviation $(\sigma)$ and coefficient of variance $(\mathrm{CV})$. Correlation is applied to measure the interdependence of two equity market returns. After preliminary analysis, the formal descriptive method of mean, standard deviation, and coefficient of variance have been applied for measuring and ranking purposes. It is also important to note that standard deviation is used for calculating the spread around the mean for every stock market data in a taken time period. This spread is particularly known as volatility and CV as a relative measure of volatility. Besides that General Autoregressive Conditional Heteroscedasticity GARCH $(1,1)$ model is employed to calculate volatility. 
Descriptive Analysis. Stock returns for all twelve stock markets are computed by taking the natural log. The mathematical equation for log returns can be expressed as follows:

$$
R_{t}=\ln \left(I_{t} / I_{t-1}\right)
$$

where: $R_{t}=$ equity returns at time $t ; I_{t}=$ financial market index at time $t ; I_{t-1}=$ equity market index at first lag of time $t$.

Unit Root Test. This study is based on time series data; therefore, stationarity of the data is an essential requirement in order to proceed with further econometric analysis. Thus, Dickey-Fuller test was employed for checking the stationarity. This method is most frequently and widely used method for financial time series for more than three decade all over the world. Dickey and Fuller (1979) have initially proposed this method and it was known as DickeyFuller method. It was further modified and renamed as Augmented Dickey-Fuller (1981). This model actually entailed on rejecting the null hypothesis of the unit root. Otherwise, the series are said to be non-stationary in support of the alternative hypothesis of stationarity. The general equation of the model is given as follows:

$$
\Delta y_{t}=\alpha_{0}+\alpha_{1} y_{t-1}+\sum_{i=1}^{n} \alpha \Delta y_{t}+e_{t},
$$

where: $\Delta=$ the first difference operator; $y=$ the time series; $t=$ time period; $\alpha_{0}=$ a constant, $e=$ white noise error; $n=$ the optimum number of lags.

Modeling Conditional Heteroscedasticity. Predicting the conditional dispersion is essential because the volatility influences the asset prices. A renowned economist named Engle (1982), established an econometric model for measuring Auto-Regressive conditional heteroscedasticity:

where: $\gamma+\sum_{i=1}^{q} \alpha_{i}=1$.

$$
\begin{gathered}
Y_{t}=\beta X_{t}+\sigma_{t} \varepsilon_{t}, \text { where } \varepsilon_{t} \sim \mathrm{N}(0,1) \\
\sigma^{2}{ }_{t}=\gamma V_{L}+\sum_{i=1}^{q} \alpha_{i}\left(\sigma_{t-i} \varepsilon_{t-i}\right)^{2},
\end{gathered}
$$

In case of ARCH (q), we allocate certain weights to long run average variance rate, $V_{L}$ : since we are dealing with a variance, $V_{L}=$ average of $L_{T}$ variance:

$$
\omega=\gamma V_{L} \text { and both } \omega>0 \text {, and } \alpha_{i}>0 \text { for all } i \text {. }
$$

Despite the fact, the errors are doubted to be serially uncorrelated, but still, errors are not independent. The existence of volatility and clustering fat tails will be there. Considering the fact we have introduced following model for the purpose of forecasting equity returns:

$$
r_{t}=\mu+\varepsilon_{t} .
$$

$r_{t}$ denotes the return in reference of time, such as daytime ' $t$ ' and $\varepsilon_{t}$ are referring independent observation from $\mathrm{N}\left(0, \sigma_{\mathrm{t}}^{2}\right)$. Through which random walk hypothesis:

$$
\sigma_{t}=\sigma^{2}
$$


Since the variance of $\varepsilon_{t}$ is to be considered constant for all the ' $t$ ' values. As discussed before, the return ' $r$ ' is homoscedastic. Another form of the serial correlation of variance can be expressed as:

$$
\sigma_{t}^{2}=\omega+\alpha \varepsilon^{2}{ }_{t-1}
$$

The above Eq. (1) is known as the autoregressive conditional heteroscedastic (ARCH). This formulation is called an Autoregressive Conditional Heteroscedastic (ARCH) approach. Since $\varepsilon_{t}^{2}$ is known as the unbiased approximation of $\sigma_{t}^{2}$, that is $E\left(\varepsilon^{2}{ }_{t}\right)=\sigma_{t}{ }^{2}$, therefore, the estimation error $v_{t}=\varepsilon^{2}{ }_{t}-\sigma_{t}{ }^{2}$, hence, the Eq. (1), $\varepsilon_{t}{ }^{2}$ can be written as follows:

$$
\varepsilon^{2}{ }_{t}=\sigma_{t}^{2}+v_{t}=\omega+\alpha \varepsilon^{2}{ }_{t-1}+v_{t} .
$$

Since Eq. (2) is known to be the AR(1) condition for the squared residual. It is also important to note that the error term $v_{t}$ is not considered constant, therefore, the Eq. (2) is to be known as the heteroscedastic $\operatorname{AR}(1)$.

The Eq. (2) could be generalized in order to contain squared residuals for lags 2, 3 and so on, as explanatory variables. The below equation is the standard representation for AR models, which is expedient to express Eq. (2) as ARCH (1). Let a $(L)$ is the pth order polynomial in lag operative $L$ then it can be written as:

$$
\alpha(L)=\alpha_{t} L+K \alpha_{p} L^{p}
$$

Then, $\mathrm{ARCH}(p)$ is:

$$
\sigma_{t}^{2}=\omega+\alpha(L) \varepsilon^{2}{ }_{t}
$$

Since we have already known in ARMA approach for the mean, As we have learned in ARMA modeling for the mean, it is not prudent to keep on rising lagged squared residuals terminologies. It is not wise to keep increasing lagged squared residual terms for clarifying the serial for explaining the serial reliance of the variance. In contrast, the parsimonious generalization of Eq. (1) to incorporate $\sigma_{t-1}^{2}$ expression as an explanatory factor as follows:

$$
\sigma_{t}^{2}=\alpha_{0}+\alpha \varepsilon_{t-1}^{2}+\beta \sigma_{t-1}^{2} .
$$

The above Eq. (3) is known as the generalized ARCH or GARCH, which was suggested by Bollerslev (1986). The Eq. (3) is a form of heteroscedastic ARMA $(1,1)$. It can be shown that Eq. (3) is an heteroscedastic ARMA $(1,1)$ pattern for the SR (squared residual), thus it can be expressed as follows:

$$
\begin{gathered}
\varepsilon_{t}^{2}{ }_{t}=\sigma_{t}^{2}+v_{t}=\omega+\alpha \varepsilon^{2}{ }_{t-1}+\beta \sigma_{t-1}^{2}+v_{t} \\
\varepsilon^{2}{ }_{t}=\omega+\alpha \varepsilon^{2}{ }_{t-1}+\beta\left(\varepsilon^{2}{ }_{t-1}-v_{t-1}\right)+v_{t} \\
\varepsilon^{2}{ }_{t}=\omega+\alpha \varepsilon^{2}{ }_{t-1}+\beta \varepsilon^{2}{ }_{t-1}-\beta v_{t-1}+v_{t} \\
\varepsilon^{2}{ }_{t}=\omega+(\alpha+\beta) \varepsilon^{2}{ }_{t-1}+v_{t}-\beta v_{t-1} .
\end{gathered}
$$

Since $\mathrm{n}_{t}$ is not the constant value thus, it is considered heteroscedastic. From the Eq. (3) $\mathrm{ARCH}(1)$ is represented as $\operatorname{GARCH}(1,1)$. Let $\beta(L)$ is the qth order polynomial in $L$ then:

$$
\beta(L)=\beta_{1} L+K \beta_{q} L^{q} .
$$


Since in realistic ARCH models the extreme orders of $q$ is required, that is the most thrifty illustration of generalized $\mathrm{ARCH}$ approach. Thus, the $\mathrm{GARCH}(p, q)$ can be written as follows:

$$
\begin{gathered}
\sigma_{t}^{2}=\omega+\sum_{i=1}^{q} \alpha_{i} \varepsilon^{2}{ }_{t-i}+\sum_{j=1}^{p} \beta_{j} \sigma^{2}{ }_{t-j} ; \\
\sigma^{2}{ }_{t}=\omega+\alpha(L) \varepsilon^{2}{ }_{t}+\beta(L) \sigma^{2}{ }_{t} .
\end{gathered}
$$

Initially, the coefficient of GARCH (1) term i.e. $\sigma_{t-1}^{2}$ shows high significance. In finance literature simply GARCH $(1,1)$ model is often used, in which conditional variance can be mentioned as below:

$$
\sigma_{t}^{2}=\omega+\alpha \varepsilon_{t-1}^{2}+\beta \sigma_{t-1}^{2} .
$$

As per the hypothesis of covariance stationarity, the unconditional variance $\sigma_{t}^{2}$ can be computed by considering the unconditional expectation of Eq. (4). We have as follows:

$$
\sigma^{2}=\omega+\alpha \sigma^{2}+\beta \sigma^{2}
$$

Later, the maximum likelihood method used for estimation. Comparing the outcome of log likelihood values, GARCH return raised assessment, which substantiated that the data is more predictable from GARCH method rather than $\mathrm{ARCH}$ process. Consequently, $\mathrm{ARCH}$ has shown one less constraint as compared to GARCH. Every parameter in GARCH model is mostly estimated through maximum likelihood approach considering similar fundamental functions of likelihood after taken into the normality assumption. While performing maximum likelihood we often opt parameters, which maximize the occurrence to a likelihood of observations. Both Schwarz criterion and Akaike information criterion regulate the likelihood for the number of parameters. The lower values of both criteria authenticate the better fitness. Since the ARCH has the higher value than GARCH for both criteria, therefore we have preferred GARCH as compered to ARCH.

As per the GARCH $(1,1)$ model developed by Engle (2001) that variance anticipated at any point of the data indicates the blend of long-run variance and variance anticipated last period, attuned to consider the extent of preceding period's observed volatility. In GARCH method approximations for capital asset returns, trailing conditional variance and sum of GARCH coefficients are very close to 1 . This indicates the stuns to the conditional variance are significantly determined by an existence of pretty long memory but because of less than 1 , it has stationary mean-reverting behavior. In easier understanding, however, volatility takes a longer time period but eventually, it reverted back to its mean value. This entails that present evidence does not affect on long-term predictions. Studies regarding SV models are very rich and several important kinds of literature are available (e.g., Shephard 1996; Ghysels et al. 1996; etc.). Therefore, the focus of this research study is to provide an outline of the foremost methods with specific prominence on the initiation of volatility calculations in every sort of model description and inferential method.

We allocate certain weight to long run average variance (LRAV) rate in GARCH $(1,1)$ model. Now, solving the Eq. (5), we have following equation:

$$
V_{L}=\sigma^{2}=\frac{\omega}{1-\alpha-\beta} \text {. }
$$


The long run average variance (LRAV) for the equity returns can be calculated by employing this formula $\sqrt{\omega /(1-\alpha-\beta)}$, as explained by Engle (2001). For this unconditional variance, it is necessary to follow the condition $\alpha+\beta<1$ and both coefficient should be non-negative as, $\alpha \geq 0, \beta \geq 0$ and $\omega>0$.

\section{Estimations and results}

Results of this study are presented in four parts. In initial part, the graphical exhibition of time series based on historic data is enumerated, followed by the descriptive analysis of stock return, standard deviation, a coefficient of variation (CV) and correlation analysis. The equality of variance is given in third part by conducting an inferential analysis. An econometric model to confirm the descriptive and inferential analysis is given in final part of the study.

Graphical Depiction of Time series. Figure 1 shows the graphical depiction of all the stock market indices for the historic times series data. It exhibits certain sudden rise and fall in the data, which evidenced an asymmetrical spread. Besides that, excluding the equity markets namely BVSP, Nikkei and HSI, all others shows index lower than 10,000 points at the initiating period of a sample. There is an existence of association among these equity markets. Lastly, the graph shows, the most of the equity markets go down in terms of investment and considerable collapse is witnessed particularly during the third quarter of 2008, this was the period when a seed of financial crises was sown.

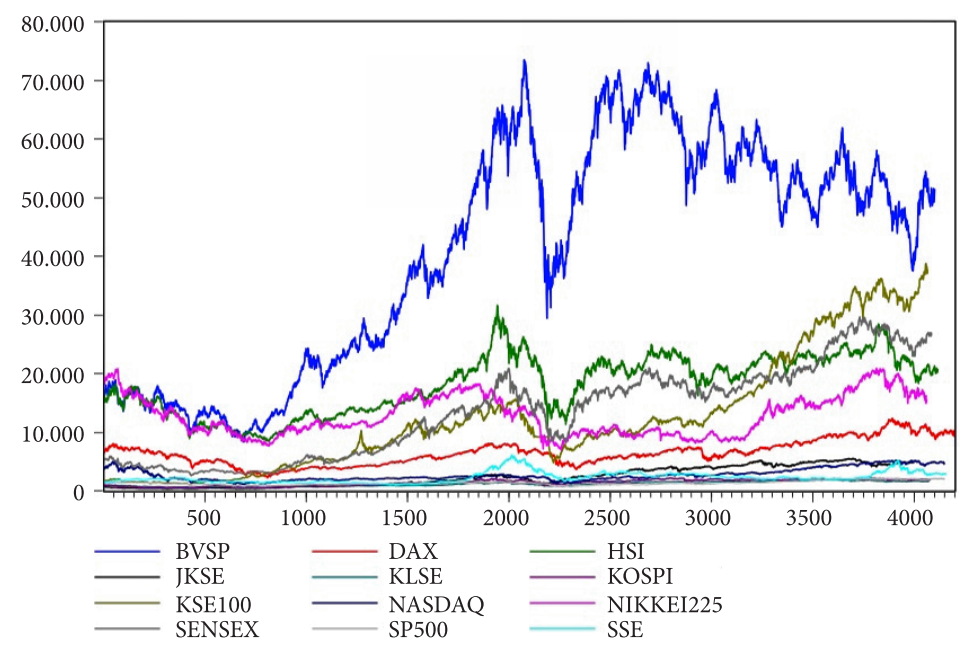

Fig. 1. Historical time series graph (source: authors' estimation)

Descriptive analysis. The initial part of the results is to grasp the better comprehension of the data that used in this study. The descriptive analysis is given the below tables, which present the peculiar characteristics and properties of both developed and emerging markets at a glance. With the intention to give ease to better understanding, the average stock returns are converted into annual returns. Table 1 and Table 2 show the values of Jarque-Bera, kurtosis, skewness, and the probabilities about the equity returns of every related index being part of this study. The probability distributions' deviation on both sides of the mean is measured 
through skewness. However, the peak or flatness of the data shows the normality of the distribution, which is measured through kurtosis. The results show that the market returns of Nasdaq are positively skewed; in contrast to rest of the indices, which are negatively skewed. This shows that the tail for Nasdaq is longer and fatter to the right end of probability density function, though rest of the equity markets exhibiting a flatter or longer tails to the left end. Results of the kurtosis values of all the stock indices are showing leptokurtic. Keeping before these outcomes, we can assume that our data is not normally distributed, which entails zero skewness and three coefficient of kurtosis. Similar results are also authenticated by JacqueBera statistic test of normality. As it can observe by having looked at the values of probability for every individual variable, the null hypothesis can be rejected even at $1 \%$ level. Hence, it failed for accepting the null hypothesis; this means the data in this study is not normally distributed. This indicates the inefficiencies of markets.

It is clear from the Table 1 that KSE100 has the highest annual returns of $24.03 \%$ with standard deviation of 0.014 (risk or volatility), but the coefficient of variation has the highest value of $80.34 \%$, which means the risk-return trade-off is very high, followed by JKSE $14.76 \%$ with 0.014 SD and CV is $70.53 \%$ that is again risk-return trade-off is very high. The SENSEX $11.85 \%$ annual returns with SD of 0.015 and CV of $58.52 \%$ and BVSP $8.13 \%$ annual returns and SD is 0.018 and CV is $47.53 \%$. Although, SSE has $5.49 \%$ and KLSE has $5.04 \%$ annual returns, and SDs are 0.016 and 0.009 , CVs are $39.67 \%$ and $33.78 \%$ respectively. KOSPI is, however, getting the least returns of $4.56 \%$ annually with SD of 0.015 and CV is $38.15 \%$. The KLSE demonstrated the lowest risk-return trade-off in all emerging markets; however, the annual stock return is also nominal i.e. 5.04\%.

Table 1. Descriptive statistics for emerging stock markets

\begin{tabular}{|l|c|c|c|c|c|c|c|}
\hline $\begin{array}{c}\text { Descriptive } \\
\text { Statistics }\end{array}$ & R_KSE & R_SENSEX & R_SSE & R_KOSPI & R_KLSE & R_JKSE & R_BVSP \\
\hline Mean & 0.000801 & 0.000395 & 0.000183 & 0.000152 & 0.000168 & 0.000492 & 0.000271 \\
\hline Median & 0.001050 & 0.000952 & 0.000105 & 0.000630 & 0.000383 & 0.001158 & 0.000423 \\
\hline Maximum & 0.085071 & 0.159900 & 0.094008 & 0.112844 & 0.160204 & 0.076231 & 0.136766 \\
\hline Minimum & -0.077414 & -0.118092 & -0.092562 & -0.128047 & -0.155682 & -0.109540 & -0.120961 \\
\hline Std. Dev. & 0.013708 & 0.015400 & 0.016242 & 0.015866 & 0.009546 & 0.014085 & 0.018276 \\
\hline Skewness & -0.268541 & -0.198732 & -0.321592 & -0.571158 & -0.505349 & -0.674755 & -0.047559 \\
\hline Kurtosis & 6.532858 & 10.005415 & 7.724544 & 9.165430 & 61.092560 & 9.309546 & 6.580257 \\
\hline Jarque-Bera & 2163.37 & 8380.01 & 3939.79 & 6680.68 & 572755.14 & 6936.86 & 2191.33 \\
\hline Probability & 0.0000 & 0.0000 & 0.0000 & 0.0000 & 0.0000 & 0.0000 & 0.0000 \\
\hline Sum & 3.255446 & 1.614048 & 0.762558 & 0.620848 & 0.684899 & 1.969125 & 1.113019 \\
\hline Sum Sq. Dev. & 0.763815 & 0.968619 & 1.096850 & 1.026341 & 0.370995 & 0.793163 & 1.369125 \\
\hline CV & 80.34 & 58.52 & 39.67 & 38.15 & 33.78 & 70.53 & 47.53 \\
\hline Observations & 4066 & 4085 & 4159 & 4078 & 4072 & 3999 & 4100 \\
\hline
\end{tabular}

Source: authors' estimation 
The average annual returns of the developed markets are nominal and not significant, S\&P500 has the highest annual returns of $2.64 \%$ with standard deviation of 0.013 (risk or volatility) and CV is $25.05 \%$ that shows the risk-return trade-off is the lowest among emerging and developed markets followed by DAX 2.58\%, and then HSI 1.32\% and Nasdaq 1.14\% annual returns. However, Nekkei225 is the only market, which shows negative annual returns of $-1.47 \%$. Results of standard deviation (volatility or risk) of other developed stock markets are 0.017 for Nasdaq with CV of $38.14 \%, 0.015$ for HSI with CV of $27.46 \%$, and DAX has SD of 0.015 and CV is $32.69 \%$ and SD of Nekkei225 is 0.016 with CV of $26.64 \%$ on daily calculation as showed in Table 2.

Table 2. Descriptive statistics for developed stock markets

\begin{tabular}{|l|c|c|c|c|c|}
\hline $\begin{array}{c}\text { Descriptive } \\
\text { Statistics }\end{array}$ & R_NIKKEI & R_HSI & R_DAX & R_SP500 & R_NASDAQ \\
\hline Mean & -0.000049 & 0.000044 & 0.000086 & 0.000088 & 0.000038 \\
\hline Median & 0.000283 & 0.000085 & 0.000757 & 0.000533 & 0.000812 \\
\hline Maximum & 0.132346 & 0.134068 & 0.107975 & 0.109572 & 0.132546 \\
\hline Minimum & -0.121110 & -0.135820 & -0.074335 & -0.094695 & -0.101684 \\
\hline Std. Dev. & 0.015614 & 0.015268 & 0.015469 & 0.012598 & 0.016590 \\
\hline Skewness & -0.394155 & -0.077308 & -0.018723 & -0.189994 & 0.025508 \\
\hline Kurtosis & 8.999111 & 10.832657 & 6.996310 & 10.973343 & 8.359654 \\
\hline Jarque-Bera & 6196.37 & 10523.16 & 2795.75 & 11015.35 & 4966.44 \\
\hline Probability & 0.0000 & 0.0000 & 0.0000 & 0.0000 & 0.0000 \\
\hline Sum & -0.198863 & 0.179959 & 0.360416 & 0.366237 & 0.158910 \\
\hline Sum Sq. Dev. & 0.990122 & 0.959019 & 1.004963 & 0.658372 & 1.141660 \\
\hline CV & 26.64 & 27.46 & 32.69 & 25.05 & 38.14 \\
\hline Observations & 4062 & 4115 & 4201 & 4149 & 4149 \\
\hline
\end{tabular}

Source: authors' estimation

Correlation analysis. As displayed in historic time series graphical presentation in this paper that most of the equity markets are following the similar pattern. Thus, the correlation coefficients are calculated as the ceremonial form of analysis to investigate the relationship between the returns of these equity markets. Table 3 exhibits that every equity market chosen for this study has positive interdependence with each other. To substantiate one of the objectives of this study to assess the shock transmission between developed and developing markets, the existence of a correlation between these markets is varied handy. Table 3 shows the summary of correlation matrix for chosen groups of equity markets at $5 \%$ significance level.

The results in Table 3 show fascinating outcomes regarding the existence of high correlation among developed stock markets. Elevated positive correlation entails that the increase in one variable will be followed by the increase in another. Table 3 further shows that all the developed and emerging markets are depicting low association with SSE excluding HSI and BVSP. This association may be because of Chinese stock market Shanghai Index, which significantly less magnetizes the foreign investment as compared to other indices related to 
China like Hong Kong Stock Exchange (HSI), which has a significant relationship among all the emerging and developed markets except Nikkei225. The Nikkei225 has a positive and significant relationship with other developed stock markets except for HSI and it is also noted Nikkei225 does not have the significant association with emerging markets except KSE100. Other developed stock markets have significant association on each other. DAX has a significant positive association with all the emerging and developed markets. Both S\&P500 and Nasdaq have the significant positive association with all the emerging and developed markets except BVSP and SSE.

In Table 3, all associations are not significant in emerging markets; BVSP has a significant positive relationship with all emerging and developed markets except Nasdaq, Nikkei225, and S\&P500. KSE100 has the positive significant correlation with all the emerging and developed markets except SSE. Emerging stock markets, KLSE and JKSE have significant positive association with all other developed and emerging markets except Nikkei225, and SSE. KOSPI and SENSEX have a positive and significant relationship with all the developed and emerging markets except Nikkei225. The significance and non-significance of correlation amongst the market demonstrated the extent of shock transmissions among the stock markets.

Table 3. Correlation analysis

\begin{tabular}{|l|c|c|c|c|c|c|c|c|c|c|c|c|}
\hline & BVSP & DAX & HIS & JKS & KLS & KOS & KSE & NAS & NIK & SENS & S\&P & SSE \\
\hline BVSP & 1.00 & & & & & & & & & & & \\
\hline DAX & 0.50 & 1.00 & & & & & & & & & & \\
\hline H.S.I & 0.87 & 0.77 & 1.00 & & & & & & & & & \\
\hline JKSE & 0.80 & 0.72 & 0.81 & 1.00 & & & & & & & & \\
\hline KLSE & 0.81 & 0.75 & 0.87 & 0.97 & 1.00 & & & & & & & \\
\hline KOSPI & 0.92 & 0.67 & 0.90 & 0.93 & 0.95 & 1.00 & & & & & & \\
\hline KSE100 & 0.60 & 0.82 & 0.75 & 0.88 & 0.88 & 0.80 & 1.00 & & & & & \\
\hline NASDAQ & 0.33 & 0.90 & 0.64 & 0.66 & 0.69 & 0.55 & 0.79 & 1.00 & & & & \\
\hline NIKKEI & 0.04 & 0.66 & 0.42 & 0.20 & 0.29 & 0.23 & 0.51 & 0.70 & 1.00 & & & \\
\hline SENSEX & 0.84 & 0.79 & 0.90 & 0.94 & 0.95 & 0.94 & 0.91 & 0.69 & 0.35 & 1.00 & & \\
\hline SP500 & 0.35 & 0.92 & 0.68 & 0.67 & 0.71 & 0.58 & 0.86 & 0.94 & 0.76 & 0.73 & 1.00 & \\
\hline SSE & 0.63 & 0.55 & 0.67 & 0.43 & 0.46 & 0.55 & 0.39 & 0.31 & 0.11 & 0.57 & 0.35 & 1.00 \\
\hline
\end{tabular}

Source: authors' estimation

Graphical Analysis for the Stationarity. Bristling with an issue of non-stationarity is state of obvious observation. The issue is often cropped up due to the precise fact that the properties of time series data are driven from the random walk (See Fig. 2). One important factor of this result because whole obtainable information is bared in the equity price then the paramount estimation for the prices of following day will be the stock prices of today. This course of action guarantees that every index is stationary, the same can be further observed by having a look on Table 4 and Table 5 , as we refute the null hypotheses that data contains unit root in all the time series of returns. We ratify that by converting the data, we may lose 

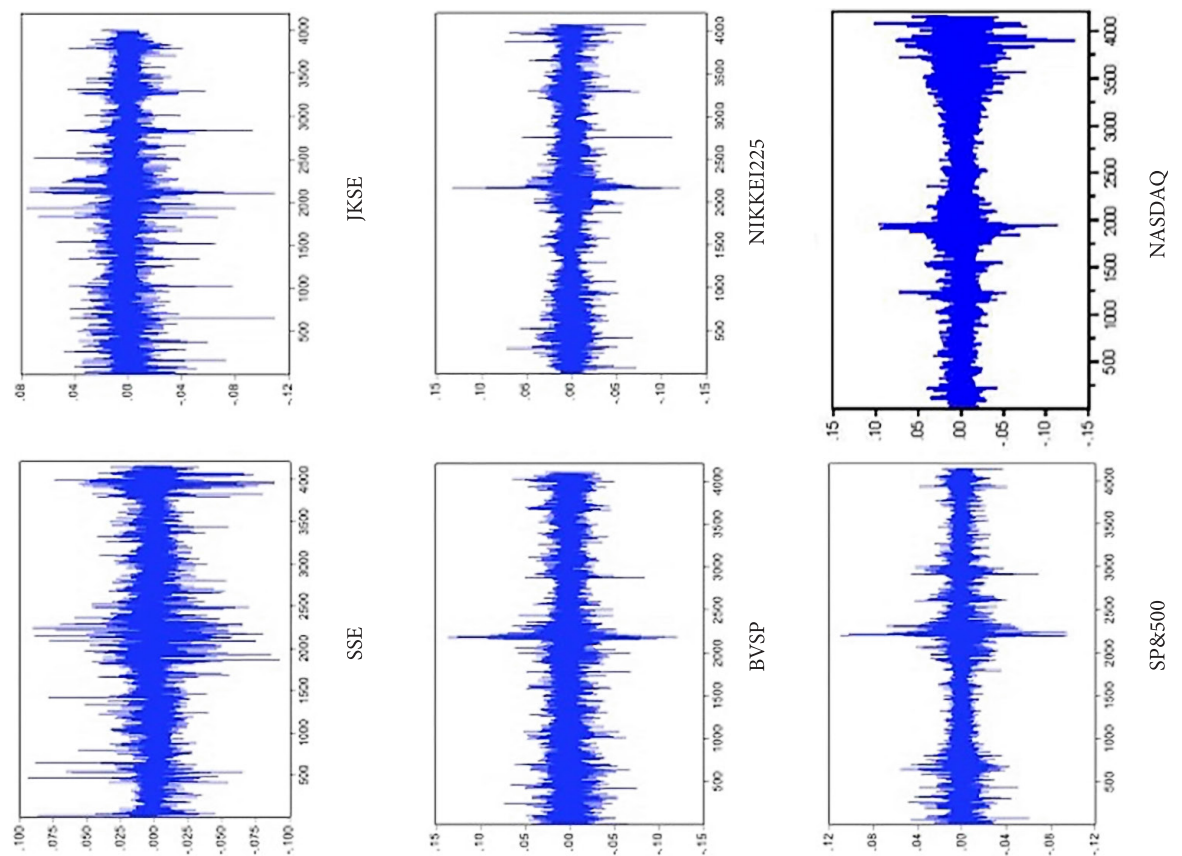

菊
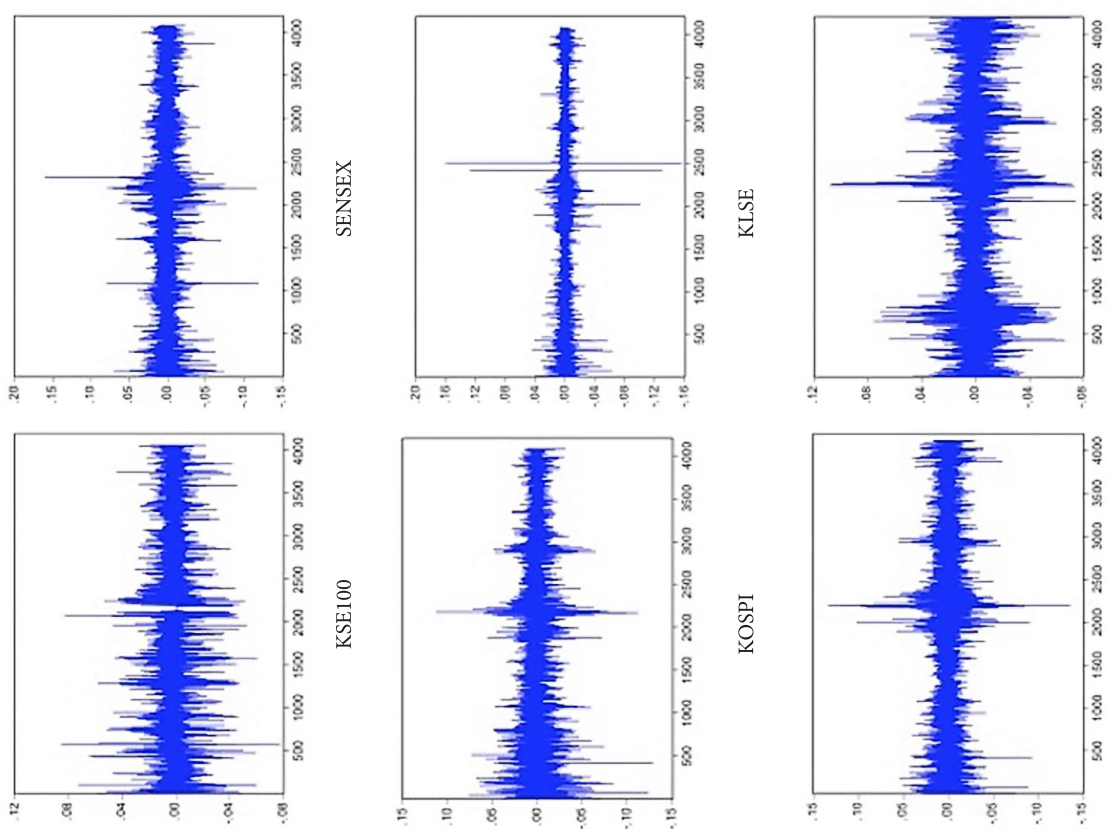

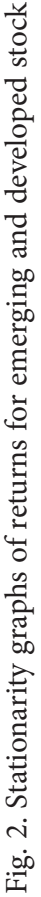


some part of information in the process, and however, responding to our assumption of random walk, it was essential to obtain stationarity before proceeding further analysis (see Table 4 and Table 5).

Unit Root Statistics. Table 4 shows the results of ADF test without structural break, which shows all the data series, are stationary. One important cause for this outcome because the entire existing evidence is exposed in the equity price, then the paramount estimation for the prices of following day will be the stock prices of today. Besides that, when the time series is drawn from random walk having a long-term owing to inappropriate pricing communication, bubbles, volatility, irregularities, and several other cyclic developments. Thus, it becomes essential to transform our data into returns in order to ensure stationarity prior any further analysis. Please also see the graphical representations of stationarity from Figure 2.

This procedure is carried out to ensure the stationarity of each index. The results can be observed in Table 4. Keeping the results we refute the null hypothesis that our data has unit root for without structural break. The outcomes of ADF test confirm that our data series do not have any unit root. The fact is established by retaining null hypothesis at $5 \%$ level of significance, besides that the critical values for all stock indices are more than the corresponding t-values.

Table 4. Stationary test results for stock markets without break

\begin{tabular}{|l|c|c|c|c|c|}
\hline \multirow{2}{*}{\begin{tabular}{c} 
Stock $\begin{array}{c}\text { Markets } \\
\text { Returns }\end{array}$ \\
\cline { 3 - 5 }
\end{tabular}} & \multicolumn{2}{|c|}{$\begin{array}{c}\text { Augmented Dickey-Fuller test } \\
\text { statistic }\end{array}$} & $1 \%$ level & 5\% level & $10 \%$ level \\
\cline { 2 - 5 } & t-Statistic & Prob.* & t-Statistic & t-Statistic & t-Statistic \\
\hline R_KSE & -57.8806 & 0.0001 & -3.4318 & -2.8621 & -2.5671 \\
\hline R_SENSEX & -59.4001 & 0.0001 & -3.4318 & -2.8621 & -2.5671 \\
\hline R_SSE & -63.1505 & 0.0001 & -3.4318 & -2.8621 & -2.5671 \\
\hline R_KOSPI & -62.1401 & 0.0001 & -3.4318 & -2.8621 & -2.5671 \\
\hline R_KLSE & -63.2972 & 0.0001 & -3.4318 & -2.8621 & -2.5671 \\
\hline R_JKSE & -56.7534 & 0.0001 & -3.4318 & -2.8621 & -2.5671 \\
\hline R_BVSP & -63.0992 & 0.0001 & -3.4318 & -2.8621 & -2.5671 \\
\hline R_NIKKEI & -66.0490 & 0.0001 & -3.4318 & -2.8621 & -2.5671 \\
\hline R_HSI & -64.7620 & 0.0001 & -3.4318 & -2.8621 & -2.5671 \\
\hline R_DAX & -65.7294 & 0.0001 & -3.4318 & -2.8621 & -2.5671 \\
\hline R_SP500 & -50.1693 & 0.0001 & -3.4318 & -2.8621 & -2.5671 \\
\hline R_NASDAQ & -48.9221 & 0.0001 & -3.4318 & -2.8621 & -2.5671 \\
\hline
\end{tabular}

${ }^{*}$ MacKinnon (1996) one-sided p-values.

Source: authors' estimation

Augmented Dickey-Fuller Test with structural break. We have also employed Augmented Dickey-Fuller test to recognize the structural breaks in developed and emerging stock markets data series. The results showed that there is only one period break for all the returns of emerging and developed stock markets series. Both results of ADF with and without break 
are of same nature because all the 12 markets returns series are stationary at level as showed in Table 5. The critical values are greater than the respective t-values of ADF. The results of the Table 5 also demonstrated the break point observations and respective dates for emerging and developed markets. Thus, now, we can proceed for further econometric analysis.

Table 5. Stationary test results for stock markets with break

\begin{tabular}{|c|c|c|c|c|c|c|c|}
\hline \multirow{3}{*}{$\begin{array}{c}\text { Stock } \\
\text { Markets' } \\
\text { Returns }\end{array}$} & \multirow{2}{*}{\multicolumn{2}{|c|}{$\begin{array}{l}\text { Augmented Dickey- } \\
\text { Fuller test statistic }\end{array}$}} & \multicolumn{3}{|c|}{ Test critical values: } & \multirow{3}{*}{$\begin{array}{l}\text { Break } \\
\text { Point }\end{array}$} & \multirow{3}{*}{$\begin{array}{c}\text { Break } \\
\text { Point Date }\end{array}$} \\
\hline & & & \multirow{2}{*}{\begin{tabular}{|c|}
$1 \%$ level \\
t-Statistic
\end{tabular}} & \multirow{2}{*}{$\frac{5 \% \text { level }}{\text { t-Statistic }}$} & \multirow{2}{*}{$\begin{array}{c}10 \% \text { level } \\
\mathrm{t} \text {-Statistic }\end{array}$} & & \\
\hline & $\mathrm{t}$-Statistic & Prob. $^{*}$ & & & & & \\
\hline R_KSE & -58.2409 & $<0.01$ & -4.9491 & -4.4436 & -4.1936 & 572 & $\begin{array}{l}\text { March 18, } \\
2014\end{array}$ \\
\hline R_SENSEX & -60.4332 & $<0.01$ & -4.9491 & -4.4436 & -4.1936 & 2323 & $\begin{array}{l}\text { January } \\
31,2007\end{array}$ \\
\hline R_SSE & -63.5845 & $<0.01$ & -4.9491 & -4.4436 & -4.1936 & 2143 & $\begin{array}{l}\text { October } \\
22,2007\end{array}$ \\
\hline R_KOSPI & -63.2318 & $<0.01$ & -4.9491 & -4.4436 & -4.1936 & 71 & $\begin{array}{l}\text { March 18, } \\
2016\end{array}$ \\
\hline R_KLSE & -65.3710 & $<0.01$ & -4.9491 & -4.4436 & -4.1936 & 2498 & $\begin{array}{l}\text { June 1, } \\
2006\end{array}$ \\
\hline R_JKSE & -57.5221 & $<0.01$ & -4.9491 & -4.4436 & -4.1936 & 652 & $\begin{array}{l}\text { October } \\
31,2013 \\
\end{array}$ \\
\hline R_BVSP & -63.6481 & $<0.01$ & -4.9491 & -4.4436 & -4.1936 & 2161 & $\begin{array}{l}\text { October } \\
26,2007\end{array}$ \\
\hline R_NIKKEI & -66.8748 & $<0.01$ & -4.9491 & -4.4436 & -4.1936 & 2748 & $\begin{array}{l}\text { May 13, } \\
2005\end{array}$ \\
\hline R_HSI & -65.9545 & $<0.01$ & -4.9491 & -4.4436 & -4.1936 & 2190 & $\begin{array}{l}\text { October } 8, \\
2007\end{array}$ \\
\hline R_DAX & -66.2073 & $<0.01$ & -4.9491 & -4.4436 & -4.1936 & 2244 & $\begin{array}{l}\text { September } \\
12,2007\end{array}$ \\
\hline R_SP500 & -50.8351 & $<0.01$ & -4.9491 & -4.4436 & -4.1936 & 2205 & $\begin{array}{l}\text { September } \\
28,2007\end{array}$ \\
\hline R_NASDAQ & -49.5770 & $<0.01$ & -4.9491 & -4.4436 & -4.1936 & 72 & $\begin{array}{l}\text { March 21, } \\
2016\end{array}$ \\
\hline
\end{tabular}

${ }^{*}$ Vogelsang (1993) asymptotic one-sided p-values.

Source: authors' estimation

Homoscedasticity Tests (Inferential statistics). Bartlett's (1937) test is being used in order to establish the non-normality of the data time series. Two other tests Levene and BrownForsythe are replacements of Bartlett's test. These three tests belong to the inferential estimations, which evaluate the equality of variances for two or more than two groups. The results of p-values are less than 0.05 for all three tests, therefore, it is concluded that there is no homoscedasticity among the variables and data time series for all three tests show nonnormality as well (Table 6). 
Table 6. Homoscedasticity test

\begin{tabular}{|l|c|c|c|}
\hline \multicolumn{1}{|c|}{ Method } & Df & Value & Probability \\
\hline Bartlett & 11 & 119272 & 0.0000 \\
\hline Levene & $(11,49223)$ & 8607.05 & 0.0000 \\
\hline Brown-Forsythe & $(11,49223)$ & 5804.41 & 0.0000 \\
\hline
\end{tabular}

Source: authors' estimation

Econometric analysis. GARCH $(1,1)$ is employed through ML - ARCH (Marquardt) method by using the normal distribution. Results of the study described that $\alpha, \beta, \omega$ parameters or coefficients of GARCH $(1,1)$ are significant for all the developed and emerging financial markets, as it also estimated $\mathrm{p}<0.01$ that demonstrated the long run average variance (LRAV), and first lag returns. The trailing variance is also explaining the conditional variance in a significant manner. Results of Table 7 and Table 8 comprise of parameters estimates, these results are consistent and in lined with the previous literature regarding the time-varying volatility. Since, the values of likelihood ratios are large and significant that suggested the GARCH $(1,1)$ model is the suitable choice to present the behavior of daily returns, which has effectively captured the time-based reliance of volatility. It is also noted from the results that GARCH $(1,1)$ parameterization is statistically significant, and almost all the assessed ' $\beta$ ' coefficients in the equation of conditional variances are significantly greater than the ' $\alpha$ ' coefficients. This indicates that enormous market shocks stimulate comparatively insignificant alterations in future volatility. Finally, the values of $\alpha+\beta$ illustrated the perseverance of the conditional variance process, which is very high and frequently close to the integrated GARCH $(1,1)$ proposed by Engle (2001) and Bollerslev (1986). This infers existing evidence is also pertinent to forecast the future volatility for a long horizon.

Table 7. Econometric analysis (GARCH Coefficients) for emerging markets

\begin{tabular}{|l|c|c|c|c|c|c|c|c|}
\hline Markets & $\omega$ & $\alpha$ & $\beta$ & $\begin{array}{c}\text { Log Like- } \\
\text { lihood }\end{array}$ & $\alpha+\beta$ & $\begin{array}{c}\text { Sum of } \\
\text { GARCH } \\
\text { Coeff- } \\
\text { cients }\end{array}$ & $\begin{array}{c}\text { LRVA }= \\
\omega / \sqrt{1-} \\
\alpha-\beta\end{array}$ & $\begin{array}{c}\text { LRAV } \\
\text { in } \%\end{array}$ \\
\hline KSE100 & $7.88 \mathrm{E}-06$ & 0.171416 & 0.788533 & 12355.48 & 0.959949 & $9.60 \mathrm{E}-01$ & 0.0140026 & $1.4003 \%$ \\
\hline SENSEX & $4.28 \mathrm{E}-06$ & 0.109335 & 0.872706 & 11939.24 & 0.982041 & $9.82 \mathrm{E}-01$ & 0.0154376 & $1.5438 \%$ \\
\hline SSE & $2.50 \mathrm{E}-06$ & 0.062706 & 0.928195 & 11762.53 & 0.990901 & $9.91 \mathrm{E}-01$ & 0.0165758 & $1.6576 \%$ \\
\hline KOSPI & $1.05 \mathrm{E}-06$ & 0.075339 & 0.922403 & 11948.06 & 0.997742 & $9.98 \mathrm{E}-01$ & 0.0215641 & $2.1564 \%$ \\
\hline KLSE & $3.24 \mathrm{E}-06$ & 0.170634 & 0.819499 & 13794.26 & 0.990133 & $9.90 \mathrm{E}-01$ & 0.0181193 & $1.8119 \%$ \\
\hline JKSE & $5.98 \mathrm{E}-06$ & 0.127863 & 0.846480 & 11856.45 & 0.974343 & $9.74 \mathrm{E}-01$ & 0.0152666 & $1.5267 \%$ \\
\hline BVSP & $5.35 \mathrm{E}-06$ & 0.064357 & 0.918518 & 10961.93 & 0.982875 & $9.83 \mathrm{E}-01$ & 0.0176751 & $1.7675 \%$ \\
\hline
\end{tabular}

Source: authors' estimation

Table 7 and Table 8, further show, the sum of GARCH parameters, such as, $\alpha, \beta, \omega$ for all the stock markets approaches to 1 . The result of the sum of coefficients $\alpha+\beta$ of GARCH $(1,1)$ is less than one for all the developed and emerging markets, hence, the necessary condition 
of the model also achieved. Engle (2001) has proposed a formula $\sqrt{\omega /(1-\alpha-\beta)}$ to calculate the long run average variance (LRAV). The results of LRAV demonstrated, the KOSPI has the highest value of $2.16 \%$, and showing the highest trailing variance (TV) of 0.922 , and KLSE followed by $1.81 \%$ with 0.819 weights of trailing variance. The KSE100 has the lowest LRAV of $1.40 \%$ with the lowest weight of 0.789 for trailing variance. BVSP with $1.77 \%$ with weights for trailing variance is 0.919 and SSE has $1.66 \%$ with weights of TV is 0.928 . SENSEX and JKSE have $1.54 \%$ and $1.53 \%$ with weights for trailing variances are 0.873 and 0.846 respectively as indicated by the Table 7 .

Table 8 shows the values for developed stock markets. Nikkei225 has the highest LRAV of $1.71 \%$, and it has the weight for trailing variance is 0.875 , and followed by $1.59 \%$ for the DAX with 0.899 weights for trailing variance. The S\&P500 exhibited the lowest LRAV of $1.19 \%$ with the weight of 0.886 for trailing variance. Nasdaq and HSI have $1.48 \%$ and $1.40 \%$ LRAVs with weights for trailing variances are 0.905 and 0.925 respectively.

Table 8. Econometric analysis (GARCH Coefficients) for developed markets

\begin{tabular}{|l|c|c|c|c|c|c|c|c|}
\hline Markets & $\omega$ & $\alpha$ & $\beta$ & $\begin{array}{c}\text { Log Like- } \\
\text { lihood }\end{array}$ & $\alpha+\beta$ & $\begin{array}{c}\text { Sum of } \\
\text { GARCH } \\
\text { Coeff- } \\
\text { cients }\end{array}$ & $\begin{array}{c}\text { LRVA }= \\
\omega / \sqrt{ } 1- \\
\alpha-\beta\end{array}$ & $\begin{array}{c}\text { LRAV } \\
\text { in } \%\end{array}$ \\
\hline NIKKEI & $4.59 \mathrm{E}-06$ & 0.109418 & 0.874959 & 11624.98 & 0.984377 & $9.84 \mathrm{E}-01$ & 0.0171405 & $1.7141 \%$ \\
\hline H.S.I & $1.87 \mathrm{E}-06$ & 0.065096 & 0.925328 & 12105.26 & 0.990424 & $9.90 \mathrm{E}-01$ & 0.0139743 & $1.3974 \%$ \\
\hline DAX & $2.45 \mathrm{E}-06$ & 0.091663 & 0.898615 & 12275.91 & 0.990278 & $9.90 \mathrm{E}-01$ & 0.0158748 & $1.5875 \%$ \\
\hline S\&P500 & $1.96 \mathrm{E}-06$ & 0.099915 & 0.886154 & 13196.49 & 0.986069 & $9.86 \mathrm{E}-01$ & 0.0118612 & $1.1861 \%$ \\
\hline NASDAQ & $2.08 \mathrm{E}-06$ & 0.085402 & 0.905145 & 12135.83 & 0.990547 & $9.91 \mathrm{E}-01$ & 0.0148337 & $1.4834 \%$ \\
\hline
\end{tabular}

Source: authors' estimation

Mean Reversion Process in developed and emerging markets. Table 9 demonstrates that the sum of GARCH coefficients such as: $\alpha, \beta$, and $\omega$ for all the developed and emerging stock markets approaches to one, which is an essential condition to ensure the mean reversion variance phenomenon. As indicated by Engle (2001) the process of mean reversion becomes slower.

As exhibited in Table 9, the KOSPI has the slowest mean reversion because the sum of GARCH $(1,1)$ coefficients is the highest 9.91E-01, and followed by Nasdaq and SSE with 9.91E-01. However, the KSE100 has the highest process of mean reversion because the sum of coefficients is the lowest one that is $9.60 \mathrm{E}-01$, and followed by JKSE as the sum of GARCH coefficients is $9.74 \mathrm{E}-01$. Table 9 also shows that there is a significant evidence of ARCH and GARCH effects for all the developed and emerging stock markets (Engle 2001).

As already demonstrated that the sum of GARCH coefficients, such as, $\alpha, \beta$, and $\omega$ for all the developed and emerging stock markets are less than 1. The result of Figure 3, further substantiated that the sum of coefficients of GARCH $(1,1)$ is less than one for all the developed and emerging markets, hence, again the necessary condition of the model also accomplished. Figure 3, further portrays, the sum of GARCH coefficients such as, $\alpha, \beta$, and $\omega$ for all the developed and emerging stock markets approaches to one, which is required to have mean reverting variance process. 
Table 9. Significant and insignificant ARCH and GARCH effects for mean reversion

\begin{tabular}{|l|c|c|c|l|}
\hline Stock markets & $\begin{array}{c}\text { Sum of GARCH } \\
\text { Coefficients }\end{array}$ & $\begin{array}{c}\text { p-val } \\
\text { ARCH }(\alpha)\end{array}$ & $\begin{array}{c}\text { p-val } \\
\text { GARCH }(\beta)\end{array}$ & $\begin{array}{c}\text { Significance } \\
\text { Level }\end{array}$ \\
\hline KSE100 & $9.60 \mathrm{E}-01$ & 0.0000 & 0.0000 & Significant \\
\hline SENSEX & $9.82 \mathrm{E}-01$ & 0.0000 & 0.0000 & Significant \\
\hline SSE & $9.91 \mathrm{E}-01$ & 0.0000 & 0.0000 & Significant \\
\hline KOSPI & $9.98 \mathrm{E}-01$ & 0.0000 & 0.0000 & Significant \\
\hline KLSE & $9.90 \mathrm{E}-01$ & 0.0000 & 0.0000 & Significant \\
\hline JKSE & $9.74 \mathrm{E}-01$ & 0.0000 & 0.0000 & Significant \\
\hline BVSP & $9.83 \mathrm{E}-01$ & 0.0000 & 0.0000 & Significant \\
\hline NIKKEI225 & $9.84 \mathrm{E}-01$ & 0.0000 & 0.0000 & Significant \\
\hline H.S.I & $9.90 \mathrm{E}-01$ & 0.0000 & 0.0000 & Significant \\
\hline DAX & $9.90 \mathrm{E}-01$ & 0.0000 & 0.0000 & Significant \\
\hline S\&P500 & $9.86 \mathrm{E}-01$ & 0.0000 & 0.0000 & Significant \\
\hline NASDAQ & $9.91 \mathrm{E}-01$ & 0.0000 & 0.0000 & Significant \\
\hline
\end{tabular}

Source: authors' estimation

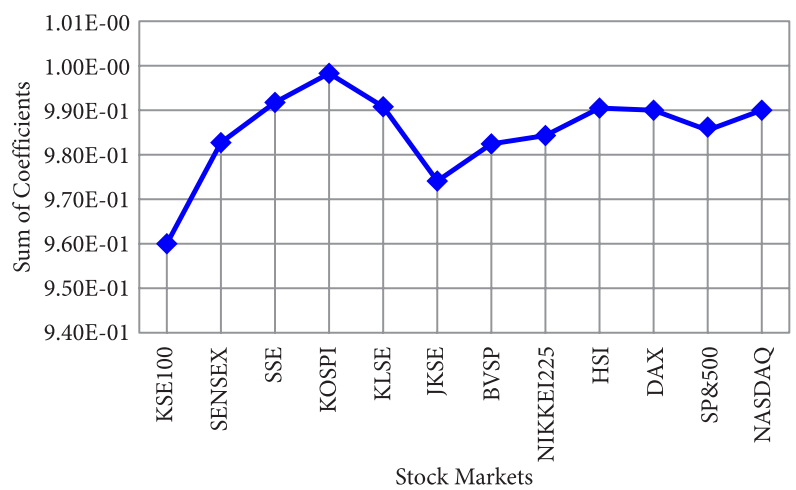

Source: authors' estimation

Fig. 3. Mean reversion phenomenon

Conditional variances for emerging and developed stock markets. The conditional variances have been estimated through integrated GARCH $(1,1)$ model for both developed and emerging financial markets. Results of Figure 4 are consistent and in lined with previous literature regarding the time-varying volatility. The following graphs patterns of developed and emerging stock markets demonstrate: 1) Regardless of the sample period, conditional variances portray positive skewness for all the data time series, 2) The conditional variances also depict surplus kurtosis because the values are greater than 3 . Hence, the volatilities for most of the markets are leptokurtic, and distributions have flatter tails as compared to the normal distribution, 3) it is much evident that during the global financial crises of 2008, the mean conditional variances were significantly high. 


\section{Discussions and conclusion}

Discussions. The results of the study indicated that there are higher returns associated with emerging markets, but volatilities are also higher, and the risk-return trade-off is much higher as compared to the developed stock markets. In contrast, developed markets are showing low returns with lower risk-return trade-offs. These results are consistent with previous researches, which were conducted for stock returns and volatilities of emerging and developed stock markets (e.g., Neaime 2016; Auer 2016; Guris, Sacildi 2016; Sarwar, Khan 2016; Bahloul, Bouri 2016; Choi et al. 2016; Goetzmann, Jorion 1999; etc.). Correlation analysis revealed the significant positive correlation among the developed markets, but emerging and

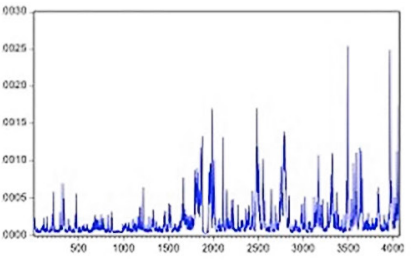

KSE100

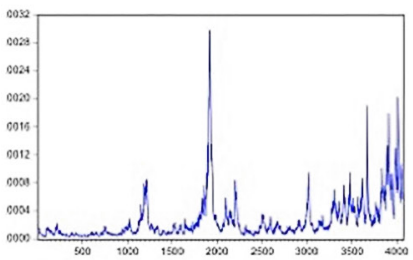

KOSPI

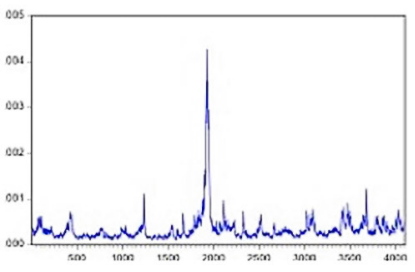

BVSP

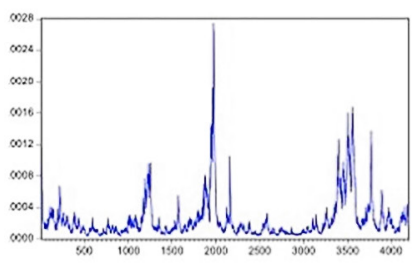

DAX

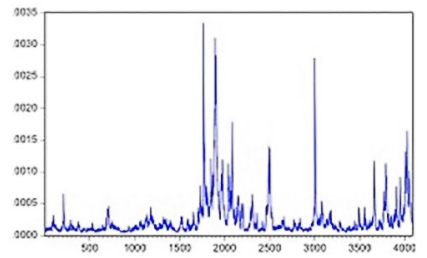

SENSEX

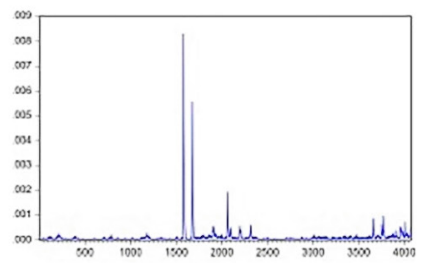

KLSE

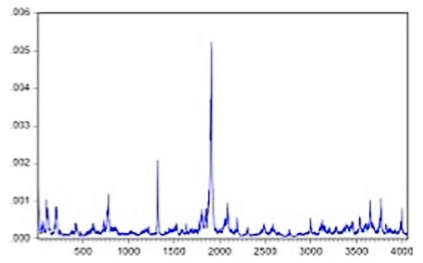

NIKKEI225

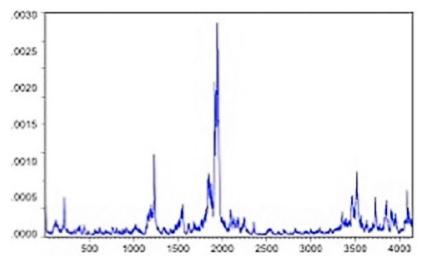

SP $\& 500$

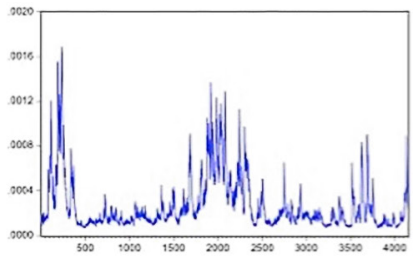

SSE

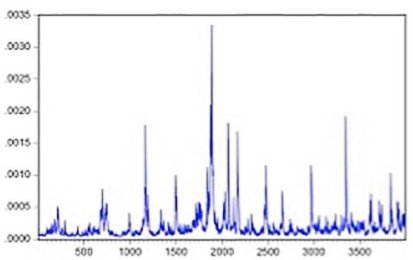

JKSE

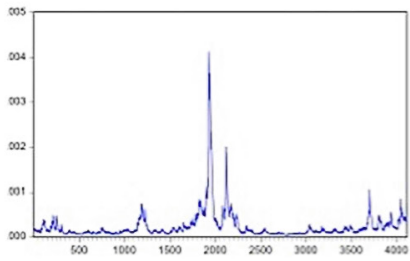

HSI

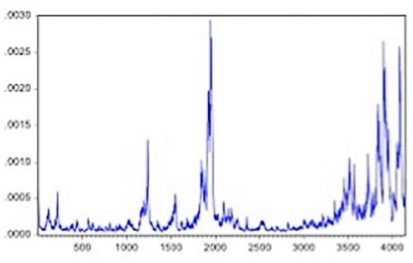

NASDAQ

Source: authors' estimation

Fig. 4. Conditional variances for emerging and developed stock markets 
developed markets have shown relatively insignificant correlation by enlarge. These results are also consistent with previous studies (e.g., Li 2016; Li et al. 2016; Mobarek, Mollah 2016; Bentes 2016; Kambouroudis et al. 2016; Xiao, Dhesi 2010; Diebold, Yilmaz 2009; Harris, Pisedtasalasai 2006; Wagner, Szimayer 2004; Ng 2000; Hu et al. 1997; etc.)

Results of our study demonstrate the sum of GARCH coefficients for all the developed and emerging stock markets are significant, which illustrated the long run average variance, and trailing variance are explaining the conditional variance in a significant manner. The results are consistent and in lined with previous literature regarding the time-varying volatility (e.g., Borland 2016; Baruník et al. 2016; Singh et al. 2016; Mukherjee, Mishra 2010; Joshi 2011; Guris, Sacildi 2016; etc.).

Finally, the sum of GARCH confidents exhibited the persistence of the conditional variance process, which is very high and frequently close to the integrated GARCH $(1,1)$ proposed by Engle (2001) and Bollerslev (1986). This infers existing evidence is also pertinent to forecast the future volatility for a long horizon as concluded in previous literature (e.g., Neaime 2016; Auer 2016; Guris, Sacildi 2016; Sarwar, Khan 2016; Beirne et al. 2013; Wang et al. 2005; Li, Majerowska 2008; etc.). The sum of GARCH coefficients for all the developed and emerging stock markets approaches to one that is the basic condition required for mean reversion process. According to Engle (2001), as the process of mean reversion becomes slower, these results are consistent to the previous research studies (e.g., Vveinhardt et al. 2016; Caporale, Sousa 2016; Mirza et al. 2016; Worthington, Higgs 2004; Domowitz et al. 1997; etc.)

Conclusion. This research measures the volatilities between important emerging and developed stock markets and to ascertain a relationship between volatilities and stock returns. This research paper also analyses the mean reversion phenomenon in emerging and developed stock markets. Descriptive statistics showed that the emerging markets have higher returns with the higher risk-return trade-off. In contrast, developed markets have low annual returns with the low risk-return trade-off. Correlation analysis showed the significant positive correlation among the developed markets, but emerging and developed markets have shown relatively insignificant correlation. The econometric analysis showed that the values of likelihood ratios are large and significant that suggested the GARCH $(1,1)$ model is the suitable choice to present the behavior of daily returns, which has effectively captured the time-based reliance of volatility. It is also noted from the results that $\operatorname{GARCH}(1,1)$ parameterization is statistically significant, and almost all the assessed ' $\beta$ ' coefficients in the equation of conditional variance are significantly greater than the ' $\alpha$ ' coefficients. This indicates that enormous market shocks stimulate comparatively insignificant alterations in future volatility. Finally, the values of $\alpha+\beta$ illustrated the perseverance of the conditional variance process, which is very high and frequently close to the integrated GARCH $(1,1)$. This concluded the existing evidence is also pertinent to forecast the future volatility for a long horizon. The results further concluded that the sum of GARCH coefficients for all the developed and emerging stock markets approaches to one, which is required to have the Mean reverting variance process. Thus, there is a significant evidence of $\mathrm{ARCH}$ and $\mathrm{GARCH}$ effects for all the developed and emerging stock markets. 


\section{References}

Auer, B. R. 2016. On time-varying predictability of emerging stock market returns, Emerging Markets Review 27: 1-13. https://doi.org/10.1016/j.ememar.2016.02.005

Baele, L. 2005. Volatility spillover effects in European equity markets, Journal of Financial and Quantitative Analysis 40(02): 373. https://doi.org/10.1017/S0022109000002350

Bahloul, W.; Bouri, A. 2016. The impact of investor sentiment on returns and conditional volatility in U.S. futures markets, Journal of Multinational Financial Management 36: 89-102. https://doi.org/10.1016/j.mulfin.2016.07.003

Banerjee, A.; Sarkar, S. 2006. Modeling daily volatility of the Indian stock market using intraday data, Working Paper No. 588 [online], [cited 12 April 2017]. Available from Internet: http://financelab. iimcal.ac.in/resdoc/WPS-588.pdf

Bartlett, M. S. 1937. Properties of sufficiency and statistical tests, Proceedings of the Royal Statistical Society Series A: Mathematical, Physical and Engineering Sciences 160(901): 268-282. https://doi.org/10.1098/rspa.1937.0109

Baruník, J.; Kočenda, E.; Vácha, L. 2016. Asymmetric connectedness on the U.S. stock market: bad and good volatility spillovers, Journal of Financial Markets 27: 55-78. https://doi.org/10.1016/j.finmar.2015.09.003

Beirne, J.; Caporale, G. M.; Ghattas, M. S.; Spagnolo, N. 2013. Volatility spillovers and contagion from mature to emerging stock markets, Review of International Economics 21(5): 1060-1075. https://doi.org/10.1111/roie.12091

Bekaert, G. 1995. Market integration and investment barriers in emerging equity markets, World Bank Economic Review 9(1): 75-107. https://doi.org/10.1093/wber/9.1.75

Bekaert, G.; Erb, C. B.; Harvey, C. R.; Viskanta, T. E. 1997. What matters for emerging equity market investments?, Emerging Markets Quarterly 1(2): 17-46.

Bekaert, G.; Erb, C. B.; Harvey, C. R.; Viskanta, T. E. 1998. Distributional characteristics of emerging market returns and asset allocation, Journal of Portfolio Management 24(2): 101-116. https://doi.org/10.3905/jpm.24.2.102

Bekaert, G.; Harvey, C. R. 1997. Emerging equity market volatility, Journal of Financial Economics 43(1): 29-77. https://doi.org/10.1016/S0304-405X(96)00889-6

Bentes, S.R. 2016. On the conditional behavior of stock market volatility: a sub-sample analysis using the FIGARCH approach for developed and emerging markets, Acta Physica Polonica A 129(5): 997-1003.

Bollerslev, T. 1986. Generalized autoregressive conditional heteroskedasticity, Journal of Econometrics 31(3): 307-327. https://doi.org/10.1016/0304-4076(86)90063-1

Borland, L. 2016. Exploring the dynamics of financial markets: from stock prices to strategy returns, Chaos, Solitons \& Fractals 88: 59-74. https://doi.org/10.1016/j.chaos.2016.03.014

Bouri, E.; Demirer, R. 2016. On the volatility transmission between oil and stock markets: a comparison of emerging importers and exporters, Economia Politica 33(1): 63-82. https://doi.org/10.1007/s40888-016-0022-6

Cakici, N.; Tang, Y.; Yan, A. 2016. Do the size, value, and momentum factors drive stock returns in emerging markets?, Journal of International Money and Finance 69: 179-204. https://doi.org/10.1016/j.jimonfin.2016.06.001

Caporale, G. M.; Sousa, R. M. 2016. Consumption, wealth, stock and housing returns: evidence from emerging markets, Research in International Business and Finance 36: 562-578.

https://doi.org/10.1016/j.ribaf.2015.01.001 
Caporale, G. M.; Spagnolo, N. 2010. Stock market integration between three CEECs, Russia and the UK, Working Paper No. 10-02 [online], [cited 25 August 2016]. Centre for Empirical Finance, Brunel University, London, UK. Available from Internet: http://qwww.brunel.ac.uk/_data/assets/ pdf_file/0020/82028/1002.pdf

Cappiello, L.; Gerard, B.; Kadareja, A.; Manganelli, S. 2006. Financial integration of new EU member states, Working Paper no. 683. European Central Bank, Frankfurt.

Chelley-Steeley, P. L. 2005. Modeling equity market integration using smooth transition analysis: a study of Eastern European stock markets, Journal of International Money and Finance 24(5): 818831. https://doi.org/10.1016/j.jimonfin.2005.04.007

Chen, J.; Mancini-Griffoli, T.; Sahay, R. 2014. Spillovers from United States monetary policy on emerging markets: different this time?, IMF working, No., WP/14/240. International Monetary Fund.

Chiang, T. C.; Doong, S. C. 2001. Empirical analysis of stock returns and volatility: evidence from seven Asian stock markets based on TAR-GARCH model, Review of Quantitative Finance and Accounting 17(3): 301-318. https://doi.org/10.1023/A:1012296727217

Choi, J. H.; Kalay, A.; Sadka, G. 2016. Earnings news, expected earnings, and aggregate stock returns, Journal of Financial Markets 29: 110-143. https://doi.org/10.1016/j.finmar.2016.02.001

Choo, W. C.; Loo, S. C.; Ling, L. B.; Ung, S. N. 2011. Return and volatility spillover between large and small stocks in Bursa Malaysia, International Journal of Business and Social Sciences 2(2): 176-185 [online], [cited 26 August 2016]. Available from Internet: http://ijbssnet.com/journals/ Vol._2_No._2;_February_2011/21.pdf

Chou, R. Y.; Lin, J. L.; Wu, C. S. 1999. Modeling the Taiwan stock market and international linkages, Pacif Economic Review 4(3): 305-320. https://doi.org/10.1111/1468-0106.00081

Cifter, A.; Ozun, A. 2008. Estimating the effects of interest rates on share prices in Turkey using a multiscale causality test, Review of Middle East Economics and Finance 4(2): 68-79.

Dickey, D. A.; Fuller, W. A. 1979. Distribution of estimators for autoregressive time series with a unit root, Journal of the American Statistical Association 74(366a): 427-431. https://doi.org/10.1080/01621459.1979.10482531

Dickey, D. A.; Fuller, W. A. 1981. Likelihood ratio statistics for autoregressive time series with a unit root, Econometrica 49(4): 1057-1072. https://doi.org/10.2307/1912517

Diebold, F. X.; Yilmaz, K. 2009. Measuring financial asset return and volatility spillovers, with application to global equity markets, The Economic Journal 119, 534: 158-171. https://doi.org/10.1111/j.1468-0297.2008.02208.x

Domowitz, I.; Glen, J.; Madhavan, A. 1997. Market segmentation and stock prices: evidence from an emerging market, Journal of Finance 52(3): 1059-1085. https://doi.org/10.1111/j.1540-6261.1997.tb02725.x

Égert, B.; Kočenda, E. 2007. Interdependence between Eastern and Western European stock markets: evidence from intraday data, Economic Systems 31(2): 184-203. https://doi.org/10.1016/j.ecosys.2006.12.004

Engle, R. 2001. GARCH 101: The Use of ARCH/GARCH models in applied econometrics, Journal of Econometric Perspectives 15(4): 157-168. https://doi.org/10.1257/jep.15.4.157

Engle, R. F. 1982. Autoregressive conditional heteroskedasticity with estimates of the variance of UK inflation, Econometrica 50(4): 987-1007. https://doi.org/10.2307/1912773

Engle, R. F.; Kroner, K. F. 1995. Multivariate simultaneous generalized ARCH, Econometric Theory 11(1): 122-150. https://doi.org/10.1017/S0266466600009063

Erb, C. B.; Harvey, C. R.; Viskanta, T. E. 1997. The making of an emerging market, Emerging Markets Quarterly 1(1): 14-19. 
Frugier, A. 2016. Returns, volatility and investor sentiment: evidence from European stock markets, Research in International Business and Finance 38: 45-55. https://doi.org/10.1016/j.ribaf.2016.03.007

Gelos, G.; Sahay, R. 2000. Financial market spillovers in transition economies, IMF Working Paper no. 00-71.

Ghosh, S.; Saggar, M. 2016. Volatility spillovers to the emerging financial markets during taper talk and actual tapering, Applied Economics Letters 24(2): 122-127. https://doi.org/10.1080/13504851.2016.1170923

Ghysels, E.; Harvey, A. C.; Renault, E. 1996. Stochastic volatility, in G. Maddala, C. Rao (Eds.). Handbook of Statistics 14: 119-191.

Gilmore, C. G.; Lucey, B. M.; McCanus, G. M. 2008. The dynamics of Central European equity market co-movements, Quarterly Review of Economics and Finance 48(3): 605-622. https://doi.org/10.1016/j.qref.2006.06.005

Gilmore, C. G.; McManus, G. M. 2002. International portfolio diversification: US and Central European equity markets, Emerging Markets Review 3(1): 69-83. https://doi.org/10.1016/S1566-0141(01)00031-0

Gilmore, C. G.; McManus, G. M. 2003. Bilateral and multilateral cointegration properties between the German and Central European equity markets, Studies in Economics and Finance 21(1): 40-53. https://doi.org/10.1108/eb028768

Goetzmann, W. N.; Jorion, P. 1999. Re-emerging markets, Journal of Financial and Quantitative Analysis 34(1): 1-32. https://doi.org/10.2307/2676244

Goudarzi, H.; Ramanarayanan, C. S. 2011. Modeling asymmetric volatility in the Indian stock market, International Journal of Business and Management 6(3). https://doi.org/10.5539/ijbm.v6n3p221

Günay, S. 2016. Performance of the Multifractal Model of Asset Returns (MMAR): evidence from emerging stock markets, International Journal of Financial studies 4(2): 11.

Guris, S.; Sacildi, I. S. 2016. Analysis of stock return volatilities using Classical and Bayesian Stochastic volatility Models in developed and emerging markets, International Journal of Advanced Research 4(9): 2077-2089. https://doi.org/10.21474/IJAR01/1693

Hanousek, J.; Kocenda, E. 2009. Intraday price discovery in emerging European stock markets, CERGEEI Working Paper no. 382.

Hanousek, J.; Kočenda, E.; Kutan, A. M. 2009. The reaction of asset prices to macroeconomic announcements in new EU markets: evidence from intraday data, Journal of Financial Stability 5(2): 199-219. https://doi.org/10.1016/j.jfs.2008.01.003

Harris, R. D. F.; Pisedtasalasai, A. 2006. Return and volatility spillovers between large and small stocks in the UK, Journal of Business Finance \& Accounting 33(9-10): 1556-1571. https://doi.org/10.1111/j.1468-5957.2006.00635.x

Harrison, B.; Moore, W. 2010. Non-linear stock market co-movement in Central and East European Countries, Chapter published in Money, Banking and Financial Markets in Central and Eastern Europe, 119-138.

Harvey, C. R. 1995. Predictable risk and returns in emerging markets, Review of Financial Studies 8(3): 773-816. https://doi.org/10.1093/rfs/8.3.773

Harvey, C. R.; Travers, K. E.; Costa, M. J. 2000. Forecasting emerging market returns using neural networks, Emerging Markets Quarterly, Summer: 1-12.

Hoque, M.; Chiou, I. 2011. The volatility transmission of stock returns across Asia, Europe, and North America, Managerial Finance 37(5): 442-450. https://doi.org/10.1108/03074351111126924

Hu, J. W. S.; Chen, M. Y.; Fok, R. C. W.; Huang, B. N. 1997. Causality in volatility and volatility spillover effects between US, Japan and four equity markets in the South China growth triangular, Journal of International Financial Markets, Institutions \& Money 7(4): 351-367.

https://doi.org/10.1016/S1042-4431(97)00027-9 
Jebran, K.; Iqbal, A. 2016. Dynamics of volatility spillover between stock market and foreign exchange market: evidence from Asian Countries, Financial Innovation 2(1).

Jochum, C.; Kirchgässner, G.; Platek, M. 1999. A long run relationship between Eastern European stock markets? Cointegration and the 1997/98 crises in emerging markets, Weltwirtschafliches Archiv 135(3): 455-479. https://doi.org/10.1007/BF02707335

Joshi, P. 2011. Return and volatility spillovers among Asian stock markets, SAGE Open 1(1): 2. https://doi.org/10.1177/2158244011413474

Kambouroudis, D. S.; McMillan, D. G.; Tsakou, K. 2016. Forecasting stock return volatility: a comparison of GARCH, Implied volatility, and realized volatility models, Journal of Futures Markets 36(12): 1127-1163. https://doi.org/10.1002/fut.21783

Kasman, A.; Torun, E. 2007. Long memory in the Turkish stock market return and volatility, Central Bank Review [online], [cited 12 April 2017]. Available from Internet: http://citeseerx.ist.psu.edu/ viewdoc/download?doi=10.1.1.597.1347\&rep=rep1\&type=pdf

Kawakatsu, H.; Morey, M. R. 1999. An empirical examination of financial liberalization and the efficiency of emerging market stock prices, Journal of Financial Research 22(4): 385-411. https://doi.org/10.1111/j.1475-6803.1999.tb00702.x

Kilic, R. 2004. On the long memory properties of emerging capital markets: evidence from Istanbul stock exchange, Applied Financial Economics 14(13): 915-922. https://doi.org/10.1080/0960310042000233638

Korkmaz, T.; Cevik, E. I.; Ozatac, N. 2009. Testing for long memory in ISE using ARFIMA-FIGARCH model and structural break test, MPRA Paper No. 71302 [online], [cited 12 April 2017]. Available from Internet: https://mpra.ub.uni-muenchen.de/71302/1/MPRA_paper_71302.pdf

Koulakiotis, A.; Papapanagos, H.; Papasyriopoulos, N. 2016. Political elections, abnormal returns and stock price volatility: the case of Greece, Investment Management and Financial Innovations 13[1(1)]: 161-169. https://doi.org/10.21511/imfi.13(1-1).2016.03

Kundu, S.; Sarkar, N. 2016. Return and volatility interdependences in up and down markets across developed and emerging countries, Research in International Business and Finance 36: 297-311. https://doi.org/10.1016/j.ribaf.2015.09.023

Li, H.; Majerowska, E. 2008. Testing stock market linkages for Poland and Hungary: a multivariate GARCH approach, Research International Business Finance 22(3): 247-266. https://doi.org/10.1016/j.ribaf.2007.06.001

Li, M. C. 2016. US term structure and international stock market volatility: the role of the expectations factor and the maturity premium, Journal of International Financial Markets, Institutions and Money 41: 1-15. https://doi.org/10.1016/j.intfin.2015.12.001

Li, T.; Zhang, F.; Zhang, H.; Chen, L. 2016. Predictability of Foodstuff Stock Returns Using Financial Ratios in the UK and US Food Markets, Advance Journal of Food Science and Technology 10(5): 336-342.

MacKinnon, J. G. 1996. Numerical distribution functions for unit root and cointegration tests, Journal of Applied Econometrics 11(6): 601-618. https://doi.org/10.1002/(SICI)1099-1255(199611)11:6<601::AID-JAE417>3.0.CO;2-T

Maheshchandra, J. P. 2012. Long of stock markets of India and China, International Journal of Science and Research 4(2).

McMillan, D. G.; Thupayagale P. 2008. Efficiency of the South African equity market, Applied Financial Economics Letters 4(5): 327-330. https://doi.org/10.1080/17446540701720717

Michael, S.; Köke, J. 2002. The Prospects of Capital Markets in Central and Eastern Europe, ZEW Discussion Paper no. 02-57: 5. 
Mirza, N.; Rahat, B.; Reddy, K. 2016. Financial leverage and stock returns: evidence from an emerging economy, Economic Research (Ekonomska Istraživanja) 29(1): 85-100. https://doi.org/10.1080/1331677X.2016.1160792

Mobarek, A.; Mollah, S. 2016. Determinants of market co-movement in developed and emerging markets, Chapter published in Global Stock Market Integration, 99-113.

Mosquera, S.; del Valle, U.; Restrepo, N.; Uribe, J. 2016. Effects of stock indices of developed and emerging markets on economic activity in Colombia: a FAVAR Approach, Lecturas de Economía 85.

Mukherjee, K. N.; Mishra, R. K. 2010. Stock market integration and volatility spillover: India and its major Asian counterparts, Research in International Business and Finance 24(2): 235-251. https://doi.org/10.1016/j.ribaf.2009.12.004

Mullineux, A.; Murinde, V. 2000. Financial sector convergence in Europe, Working Paper 03. Birmingham Business School, University of Birmingham.

Naghavi, N.; Lau, W-Y. 2016. Financial liberalization and stock market efficiency: causality analysis of emerging markets, Global Economic Review 45(4): 359-379. https://doi.org/10.1080/1226508X.2016.1198921

Neaime, S. 2016. Financial crises and contagion vulnerability of MENA stock markets, Emerging Markets Review 27: 14-35. https://doi.org/10.1016/j.ememar.2016.03.002

Ng, A. 2000. Volatility spillover effects from Japan and the US to the Pacific-Basin, Journal of international money and finance 19(2): 207-233. https://doi.org/10.1016/S0261-5606(00)00006-1

Okičić, J. 2015. An empirical analysis of stock returns and volatility: the case of stock markets from Central and Eastern Europe, South East European Journal of Economics and Business 9(1): 7-15.

Rafaqet, A.; Afzal, M. 2012. Impact of global financial crisis on stock markets: evidence from Pakistan and India, Journal of Business Management and Economics 3(7): 275-282 [online], [cited 12 April 2017]. Available from Internet: http://www.e3journals.org/cms/articles/1342846725_Afzal.pdf

Richards, A. J. 1996. Volatility and predictability in national stock markets: how do emerging and mature markets differ?, Staff Papers, International Monetary Fund 43(3): 461-501. https://doi.org/10.2307/3867551

Rousan, R.; Al-Khouri, R. 2005. Modelling market volatility in emerging markets in the case of daily data in Amman stock exchange 1992-2004, International Journal of Applied Econometrics and Quantitative Studies 2(4): 99-118 [online], [cited 12 April 2017]. Available from Internet: http:// www.usc.es/economet/Journals3/ijaeqs/ijaeqs248.pdf

Sakthivel, P.; Bodkhe, N.; Kamaiah, B. 2012. Correlation and volatility transmission across international stock markets: a bivariate GARCH analysis, International Journal of Economics and Finance 4(3). https://doi.org/10.5539/ijef.v4n3p253

Salomons, R.; Grootveld, H. 2003. The equity risk premium: emerging vs. developed markets, Emerging Markets Review 4(2): 121-144. https://doi.org/10.1016/S1566-0141(03)00024-4

Sarwar, G.; Khan, W. 2016. The effect of US stock market uncertainty on emerging market returns, Emerging Markets Finance and Trade 53(8).

Savva, C. S.; Aslanidis, N. 2009. Stock market integration between new EU member states and the Eurozone, Empirical Economics 39(2): 337-351. https://doi.org/10.1007/s00181-009-0306-6

Savva, C. S.; Osborn, D. R.; Gill, L. 2009. Spillovers and correlations between US and major European stock markets: the role of the euro, Applied Financial Economics 19(19): 1595-1604. https://doi.org/10.1080/09603100802599563

Scheicher, M. 2001. The co-movements of stock markets in Hungary, Poland and the Czech Republic, International Journal of Finance and Economics 6(1): 27-39. https://doi.org/10.1002/ijfe.141

Sehgal, S.; Garg, V. 2016. Cross-sectional volatility and stock returns: evidence for emerging markets, Vikalpa 41(3): 234-246. https://doi.org/10.1177/0256090916650951 
Serwa, D.; Bohl, M. T. 2005. Financial contagion vulnerability and resistance: a comparison of European stock markets, Economic Systems 29(3): 344-362. https://doi.org/10.1016/j.ecosys.2005.05.003

Shephard, N. 1996. Statistical Aspect of ARCH and Stochastic volatility, Chapter published in Time Series Models: 1-67.

Singh, S.; Jain, P. K.; Yadav, S. S. 2016. Volatility in stock returns, Chapter published in India Studies in Business and Economics: 145-160.

Syriopoulos, T. 2007. Dynamic linkages between emerging European and developed stock markets: has the EMU any impact?, International Review of Financial Analysis 16(1): 41-60. https://doi.org/10.1016/j.irfa.2005.02.003

Vogelsang, T. J. 1993. Essays on testing for non-stationarities and structural change in time series models: Unpublished PhD Dissertation. Princeton University, Princeton, NJ.

Voronkova, S. 2004. Equity market integration in Central European emerging markets: a cointegration analysis with shifting regimes, International Review of Financial Analysis 13(5): 633-647. https://doi.org/10.1016/j.irfa.2004.02.017

Vveinhardt, J.; Streimikiene, D.; Ahmed, R. R.; Ahmad, N.; Rehman, A. 2016. Mean reversion: an investigation from Karachi stock exchange sectors, Technological and economic development of economy 22(4): 493-511.

Wagner, N.; Szimayer, A. 2004. Local and spillover shocks in implied market volatility: evidence for the US and Germany, Research international Business Finance 18(3): 237-251. https://doi.org/10.1016/j.ribaf.2004.04.008

Wang, Y.; Gunasekarage, A.; Power, D. M. 2005. Return and volatility spillovers from developed to emerging capital markets: the case of South Asia, Contemporary Studies in Economics and Financial Analysis 86: 139-166. https://doi.org/10.1016/S1569-3759(05)86007-3

Worthington, A.; Higgs, H. 2004. Transmission of equity returns and volatility in Asian developed and emerging markets: a multivariate GARCH analysis, International Journal Finance \& Economics 9(1): 71-80. https://doi.org/10.1002/ijfe.222

Xiao, L.; Dhesi, G. 2010. Volatility spillover and time varying conditional correlation between the European and US stock markets, Global Economics and Finance Journal 3(2): 148-164.

Yang, G.; Liu, H. 2016. Financial development, interest rate liberalization, and macroeconomic volatility, Emerging Markets Finance and Trade 52(4): 991-1001. https://doi.org/10.1080/1540496X.2015.1115294

Yarovaya, L.; Brzeszczyński, J.; Lau, C. K. M. 2016. Intra- and inter-regional return and volatility spillovers across emerging and developed markets: evidence from stock indices and stock index futures, International Review of Financial Analysis 43: 96-114. https://doi.org/10.1016/j.irfa.2015.09.004

Yavas, B. F.; Rezayat, F. 2016. Country ETF returns and volatility spillovers in emerging stock markets, Europe and USA, International Journal of Emerging Markets 11(3): 419-437. https://doi.org/10.1108/IJOEM-10-2014-0150 